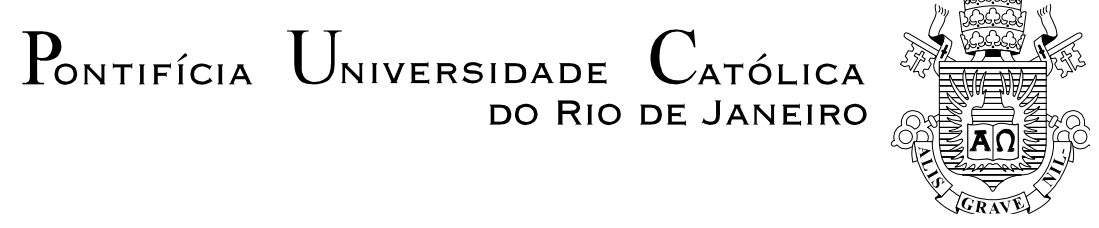

Mayumi Senra Aibe

\title{
ESCUTAR SILÊNCIOS HERDADOS
}

Tese de doutorado

Tese apresentada ao Programa de Pósgraduação em Literatura, Cultura e Contemporaneidade da PUC-Rio como requisito parcial para obtenção do grau de Doutor em Letras.

Orientador: Prof. Karl Erik Schøllhammer

Rio de Janeiro,

Abril de 2017 


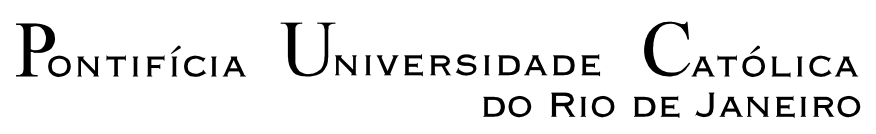

DO RIO DE JANEIRO

Mayumi Senra Aibe

\section{ESCUTAR SILÊNCIOS HERDADOS}

Tese apresentada como requisito parcial para obtenção do grau de Doutor pelo Programa de Pós-graduação em Literatura, Cultura e Contemporaneidade do Departamento de Letras do Centro de Teologia e Ciências Humanas da PUC-Rio. Aprovada pela Comissão Examinadora abaixo assinada.

Prof. Karl Erik Schøllhammer

Orientador

Departamento de Letras - PUC-Rio

Prof. Frederico Oliveira Coelho

Departamento de Letras - PUC-Rio

Prof. Marília Rothier Cardoso

Departamento de Letras - PUC-Rio

Prof. Paloma Vidal

Unifesp

Prof. Pedro Rabelo Erber

Cornell University

Prof. Monah Winograd

Coordenadora Setorial de Pós-Graduação e Pesquisa do

Centro de Teologia e Ciências Humanas - PUC-Rio

Rio de Janeiro, 11 de abril de 2017. 
Todos os direitos reservados. É proibida a reprodução total ou parcial do trabalho sem autorização da universidade, da autora e do orientador.

\section{Mayumi Senra Aibe}

Mestre em Literatura, Cultura e Contemporaneidade pela PUCRio, com a dissertação Said e Barthes: Orientes possíveis nas escritas de si. Entre 2014 e 2015, realizou pesquisa de doutorado na Universidade de Cornell, com apoio da bolsa CAPES/Comissão Fulbright - Estágio de Doutorando das Ciências Humanas, Ciências Sociais, Letras e Artes nos EUA. Graduada em Jornalismo pela Escola de Comunicação da UFRJ (2004), trabalhou como repórter e redatora de mídias impressas e online no jornal O Globo e em projetos de comunicação interna da Petrobras. Orientes possíveis (7 Letras, 2015) é seu livro de estreia.

Aibe, Mayumi Senra

Escutar silêncios herdados / Mayumi Senra Aibe; orientador: Karl Erik Schollhammer. - 2017.

80 f. : il. color. ; $30 \mathrm{~cm}$

Tese (doutorado)-Pontifícia Universidade Católica do Rio de Janeiro, Departamento de Letras, 2017.

Inclui bibliografia

1. Letras - Teses. 2. Escuta. 3. Silêncio. 4. Heranças. 5. Arte contemporânea. 6. Japão. I. Schollhammer, Karl Erik. II. Pontifícia Universidade Católica do Rio de Janeiro. Departamento de Letras. III. Título. 


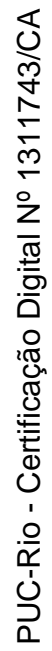

Para minha madrinha. 


\section{Agradecimentos}

Agradeço a contribuição de todos que caminharam comigo nesses últimos quatro anos e contribuíram para as reflexões e descobertas presentes neste trabalho, seja direta ou indiretamente.

Agradeço ainda à CAPES e à PUC-Rio, pelos auxílios concedidos, sem os quais este trabalho não poderia ter sido realizado.

À Comissão Fulbright e à CAPES, pela bolsa sanduíche que possibilitou minha pesquisa na Cornell University entre 2014 e 2015.

A Cornell University, pelos auxílios concedidos para que eu pudesse desfrutar de todos os recursos do campus.

A meu orientador, Karl Erik Schøllhammer, pelo apoio e incentivo durante este longo processo de pesquisa.

A Pedro Erber, por ter me recebido e auxiliado durante minha pesquisa na Cornell University.

A Marília Rothier e Pedro, pela leitura cuidadosa e por todas as sugestões antes, durante e depois da qualificação.

A Fred Coelho, Adriana Maciel e Lia Duarte Mota, por toda a troca sobre escuta e escrita.

A Paloma Vidal, muito obrigada pela disponibilidade de leitura e discussão.

A Brett de Bary, pelo incentivo fundamental.

A Izadora Zubek, pelas conversas e sugestões de bibliografia sobre silêncio e Japão.

A Elisa Castro, pelo projeto artístico que certamente inspirou este trabalho mesmo antes de ele ter começado.

Aos professores Ana Kiffer, Brett de Bary, Helena Martins, Karl Erik, Mariana Simoni, Marília Rothier, Miki Miyagawa, Naoki Sakai, Naomi Nakada Larson, Misako Suzuki, Misako Terashima Chapman, Pedro Erber, Rosana Kohl, pelas aulas que inspiraram e me ensinaram tanto durante o doutorado. 
Aos funcionários da secretaria do Departamento de Letras da PUC-Rio, em especial Chiquinha, Daniele, Di e Rodrigo, pela ajuda e paciência constantes.

Aos funcionários do Department of Romance Studies da Cornell University, pelo apoio para minha chegada e permanência em Ithaca, em especial Rob Van Brunt e Rebecca Davidson.

À equipe da Comissão Fulbright responsável pelo programa Estágio de doutorando das Ciências Humanas, Ciências Sociais, Letras e Artes nos EUA, pela ajuda inestimável durante todo o processo para a realização da pesquisa em Cornell, em especial Camila Olimpio e Luis Pedroso.

À equipe do Museu Histórico da Imigração Japonesa no Brasil, pela generosidade com que me receberam para pesquisa de arquivo em julho de 2016, em especial Mieco Yano Freitas e Sérgio Kiyoshi Fukuhara.

Aos amigos e colegas de doutorado da PUC-Rio e da Cornell University, pelo diálogo, encorajamento e aprendizado intensos.

A Aline Leal, Joana Rabelo, Felipe Wircker e Rafael Meire — pela ajuda em fazer a (às vezes difícil) ponte entre o mestrado e o doutorado.

A Beatriz Vianna, Eudes Lopes, Mee-Ju Ro, Mayumi Mizutamari, Natalie Lima e Raïssa Góes - pela presença em momentos absolutamente vitais.

A Emil e Joaquim - companheiros tão plenos de vida.

A Ivan e a minha família — para ser bem exata, por tudo. 


\section{Resumo}

Aibe, Mayumi Senra; Schøllhammer, Karl Erik. Escutar silêncios herdados. Rio de Janeiro, 2017. 80p. Tese de Doutorado - Departamento de Letras, Pontifícia Universidade Católica do Rio de Janeiro.

Questões silenciadas ao longo de décadas podem continuar a reverberar ainda hoje, atravessando gerações e experiências de vida distantes no tempo e no espaço. Anos de silêncio não são simplesmente um vazio, pois se acumulam quase imperceptivelmente. Como têm materialidade, embora extremamente sutil, eles afetam as pessoas que os herdam — seja por sorte, azar, acaso ou nascimento. Nesse sentido, esta tese de doutorado se inspira especialmente em uma fotografia na qual a artista japonesa Yamashiro Chikako aborda o legado da guerra em Okinawa, ilha no extremo sul do Japão. Para refletir sobre modos artísticos de escutar silêncios herdados, doze ensaios breves oscilam entre a pesquisa acadêmica e fragmentos de memória e de ficção. Os textos enfatizam sobretudo o potencial criativo da arte para sintonizar os aspectos sonoros, visuais e táteis do silêncio e lidar com o que não coube nos registros oficiais.

\section{Palavras-chave}

Escuta; silêncio; heranças; arte contemporânea; Japão; pós-guerra; Yamashiro Chikako; Okinawa. 


\section{Abstract}

Aibe, Mayumi Senra; Schøllhammer, Karl Erik (Advisor). Hearing inherited silences. Rio de Janeiro, 2017. 80p. Tese de Doutorado Departamento de Letras, Pontifícia Universidade Católica do Rio de Janeiro.

Unsettled issues silenced for decades may still resonate today, crossing generations and life experiences even when they are distant in time and space. Years of silence are not simply empty for they accumulate almost imperceptibly. Though extremely subtle, they have materiality, affecting those who inherited them-be it by sheer chance or birth. This dissertation takes inspiration from Japanese artist Yamashiro Chikako's work dealing with war legacy in Japan's southernmost island of Okinawa. These twelve short essays alternate between academic research and pieces of memory and fiction in order to reflect on artistic ways of hearing inherited silences. The texts highlight art's creative potential to perceive synesthetic aspects of silence (especially those related to hearing, sight, and touch), and its ability to cope with whatever was left outside official registers.

\section{Keywords}

Hearing; silence; heritage; contemporary art; Japan; postwar; Yamashiro Chikako; Okinawa. 


\section{Sumário}

$\begin{array}{ll}\text { 1. Introdução } & 14\end{array}$

$\begin{array}{ll}\text { 2. Ensaio da perda } & 17\end{array}$

3. Caiu na mão 19

4. Perto do silêncio 22

5. Zanshō no oto e Still hear the wound: projetos-relâmpago 28

6. Herança e desvio 34

$\begin{array}{lll}\text { 7. 'Nossos japoneses' } & 38\end{array}$

8. 'Uma praia bonita' - parte 1

9. 'Uma praia bonita' - parte $2 \quad 47$

10. 'Uma praia bonita' - parte 3

11. Escuta na pele, escuta em sinestesia 60

12. Sons arcaicos 69

13. Pó rosa 72

14. Referências bibliográficas $\quad 75$ 


\section{Lista de figuras}

Figura 1 - Imagem-epígrafe Erros de impressão, da série Escutar silêncios herdados (produzida pela autora)

Figura 2 - Fotografia intitulada Rodapé, da série Don't crack (produzida pela autora)

Figura 3 - Portão de Quioto (arquivo pessoal)

Figura 4 - Fotografia da série Herança Virtual, de Yamashiro Chikako

Figura 6 - Anúncio em revista da marca Semp Toshiba

Figura 7 - Livro didático de língua japonesa (arquivo pessoal)

Figura 8 - Instalação Herança Virtual no Museu de Arte Sakima

Figura 9 - Fotografia da série Coro de Melodias, de Yamashiro Chikako 


\section{Nota sobre a transcrição de nomes japoneses}

Os nomes próprios de origem japonesa foram transcritos na ordem original do sobrenome seguido pelo primeiro nome, exceto no caso de artistas e autores que usam a ordem inversa. Essa convenção também foi adotada para a transcrição de nomes de origem coreana e chinesa.

Mácrons (sinais gráficos na forma de hífen) foram incluídos para marcar as vogais longas do japonês, exceto no caso de nomes de lugares e pessoas cujas grafias já estão popularizadas em português, como Tóquio e Quioto. 
Sentiu o tapete de água sob os tênis que usava, que sentiram a madeira do barquinho, que sentiu a água amuralhada e mole na horizontal, que sentiu, sob a superfície, as correntes e os peixes, que sentiram a profundidade e o fundo arenoso, que sentiram, junto com os peixes que só nadam no fundo, algo ainda mais fundo. Não se sabe o que é, mas isso, o fundo do fundo, respondeu aos peixes, à areia e à profundidade, que responderam aos outros peixes, que responderam às correntes, que responderam à superfície, que respondeu ao casco da lancha, ou do barquinho, chame-o como quiser, o barquinho tão pequeno e frágil de tanto transportar turistas, ele respondeu às solas de borracha, que fizeram de escuta um par de pés.

Natalie Lima, Úmido tríptico 



\section{1 \\ Introdução}

Em quatro anos de pesquisa, inúmeras vezes desisti de pressupostos, temas e teorias e precisei recomeçar. Esta introdução é um exemplo disso, pois por muito tempo estive certa de que não a escreveria.

Primeiramente, abri mão do projeto com o qual fui aprovada para ingressar no doutorado, por não querer definir previamente uma linha teórica com a qual trabalhar. Restou apenas uma intenção mais forte, a de me aproximar da arte contemporânea japonesa - o que de fato ocorreu, porém de um modo imprevisto.

Assim, nesta tese não pretendo dar conta de analisar um período ou movimento artístico específico. Somente dois anos após o início da pesquisa encontrei obras que realmente me instigaram - e provavelmente foi mais interessante acontecer dessa maneira, pois esses trabalhos, da artista japonesa Yamashiro Chikako, ${ }^{1}$ ressoaram as questões mais contundentes para mim a respeito do legado da guerra no Japão, discutidas tanto em sala de aula quanto nos textos que havia lido até então.

Apesar desse contato tardio, decidi assumir o risco de tomar um novo rumo àquela altura. As obras de Yamashiro, e em especial uma fotografia, ocuparam espaço neste trabalho e inspiraram os encontros com três palavras-chave que circulam por ele, em espirais: escuta, silêncio e herança.

Como neta de japoneses nascida e criada no Brasil, que visitou o Japão apenas uma vez, devo dizer que não escrevo exatamente sobre como os artistas japoneses lidam com o legado da guerra em seu país. Em muitos momentos passo por esse tema, mas somente para me aproximar dos afetos envolvidos na proposta principal desta tese: escutar silêncios herdados.

\footnotetext{
${ }^{1}$ Conheci obras de Yamashiro Chikako por meio dos projetos Zanshō no oto: ajia, seiji, aato no mirai e e Still Hear the Wound: Toward an Asia, Politics, and Art to Come, que serão abordados no ensaio "Zanshō no oto e Still hear the wound: projetos-relâmpago", p. 28-33.
} 
A propósito, os primeiros ensaios que a compõem — "Ensaio da perda", "Caiu na mão" e "Perto do silêncio" — tratam de delinear meu próprio modo de entender e sentir a escuta de silêncios herdados (afinal, muitos outros caminhos poderiam ser seguidos).

Os ensaios "Zanshō no oto e Still hear the wound: projetos-relâmpago" e "Herança e desvio" costuram essas percepções a respeito da escuta, do silêncio e da herança com a fotografia de Yamashiro e com o projeto artístico-teórico iniciado pela professora Lee Chonghwa.

O ensaio seguinte, "Nossos japoneses", traz um certo "solavanco" no registro de escrita e também na temática. Cabe aqui destacar uma característica presente ao longo deste trabalho: os textos se fragmentam, alternam estilos de escrita, sem sustentar uma mesma voz narrativa por muito tempo.

Isso se deve a uma escolha minha, baseada principalmente na vontade de deixar que o próprio tópico a ser discutido convocasse seu modo de expressão, dependendo do momento. Esse gesto me pareceu realmente necessário, quase uma exigência do tema "escutar silêncios herdados", sempre refutando uma abordagem mais rígida.

Quanto aos fragmentos de textos dos ensaios intitulados "Uma praia bonita"”, preferi organizá-los em três grupos. Ao apresentar (em espirais) reflexões inspiradas pelo trabalho de Yamashiro, eles acolhem boa parte da pesquisa desenvolvida a partir da minha bolsa sanduíche na Universidade de Cornell, pondo em questão silêncios por trás de preconceitos e estereótipos.

Já os ensaios "Escuta na pele, escuta em sinestesia" e "Sons arcaicos" reencontram imagens criadas no decorrer da tese para pensar duas questões fundamentais: a sinestesia na escuta de silêncios herdados e a criação de um projeto coletivo para essa escuta. Além disso, levando em conta o fato de esta tese não possuir um objetivo final a ser atingido, o último ensaio mencionado pode funcionar também como uma espécie de "considerações finais".

Por fim, o ensaio "Pó rosa" chama definitivamente o texto ficcional para dentro da tese de doutorado - embora a ficção não precisasse de qualquer convite aberto. Ela já havia se infiltrado em fragmentos aqui e ali, por todo o caminho. 
A tese a seguir foi escrita com muito pouco, devo admitir - poucas palavras, poucos objetos. Ainda assim, espero que os leitores possam em algum grau se identificar com as reflexões expostas nas próximas páginas. Afinal, queiramos ou não, todos passamos pela experiência de herdar questões silenciadas durante um longo tempo. Mesmo considerando que cada um responde individualmente, conforme seus desejos e possibilidades, aos afetos provocados por essas heranças silenciosas, esta tese não deixa de ser uma sugestão para elaborarmos coletivamente modos de escutá-las.

Escutar o silêncio herdado, escutar quem escuta, escutar o que está esquecido, escutar o que está fora dos registros oficiais, fora da história...

Escutar algo à beira de desaparecer, algo à beira de começar. 


\section{2 \\ Ensaio da perda}

Um dia perdi minhas anotações para a escrita da tese de doutorado. Fragmentos de texto, ideias para os ensaios. Resumos para cada uma das palavraschave que guiam este trabalho: escuta, silêncio e herança. Os fios de costura então traçados eram de natureza frágil, delicada. Naquela manhã, tudo se radicalizou.

Antes, essas anotações estavam dispostas caoticamente nas paredes do meu pequeno escritório. No início, queria enxergá-las simultaneamente, na mesma visada. Depois me pareceu tolo esse desejo de certo modo totalizador, mas deixei que aquelas fichas continuassem a coabitar um espaço comum. Talvez assim pudessem indicar pistas sobre seus entrelaçamentos.

Esse convívio com os fragmentos começou desde a escolha pelo tema "Escutar silêncios herdados" — isso já estava em processo, mas a partir daí tomou outra proporção. Conforme a pesquisa avançava, passei a desconfiar que seria impossível contorná-los. A própria natureza dessas três palavras-chave desconvida um texto estruturado, com parágrafos longos e encadeados. Assumi-las como eixo de uma tese parece exigir que algo essencial seja sacrificado na escrita.

Em certos momentos me pareceu inútil colecionar tantas anotações e fiquei impaciente com a dificuldade em transpô-las para um texto de mais fôlego. Quis desistir. Outras vezes imaginei se seria possível entregar o trabalho em notas "cruas" de pesquisa, antes de serem editadas num discurso acadêmico.

Naquele dia, contudo, saí de casa dedicada à mesma missão das últimas semanas: esmiuçar as notas de modo a transformá-las nos ensaios da tese. Ao saltar do ônibus, no ponto próximo à universidade, sentia nos meus braços o peso da sacola com papéis soltos e fichas já organizadas.

Era um esquecimento pesando no corpo.

A sacola ficara para trás, largada no banco. 
Em busca de um reencontro com o material perdido, percorri o trajeto daquela linha de ônibus, entre o bairro da Gávea e a Central do Brasil, no Rio de Janeiro, e passei pela Lapa, onde há muitos anos estudei japonês. As aulas eram dadas num sobrado com salas improvisadas, separadas por murais de madeira. A lembrança que tenho é a da experiência de olhar para os lados e poder escutar várias professoras, lições misturadas, nessa escola de língua estrangeira sem paredes.

Ainda existem muitos sobrados nessa parte antiga da cidade, mas não consegui identificar a fachada estreita onde funcionou a escola japonesa. As casas envelhecem depressa. Algumas passaram por grandes reformas para abrigar bares e restaurantes, ou então sobrevivem precariamente, com plantas e musgos abrindo frestas na parede.

No alto de uma pensão, alguém grafitou em letras garrafais uma frase que pareceu atravessar minha procura pelo motorista, o ônibus, o banco, a sacola, os papéis, as frases anotadas em fragmentos - quiçá também a minha busca por uma escuta semelhante àquela da experiência na sala de aula vazada:

\section{XEQUE-MATE COMO NO XADREZ}

Depois de vasculhar o ponto final da linha, perdi de vez as esperanças de recuperar a pasta de trabalho. Os fragmentos colados tão precariamente continuam desaparecidos, sendo lidos por alguém bastante curioso ou jogados sem qualquer cuidado numa caçamba de lixo. Talvez entupam um bueiro da cidade. 


\section{3 \\ Caiu na mão}

As crianças usam em situações diversas estes dois verbos: cair e sumir. Caiu, sumiu. Gostam de testar se os brinquedos caem, se eles somem - o jogo é esse. Interesso-me por heranças que caem na mão, no corpo, como o brinquedo no chão: um peso despenca no ar e bate onde encontrar resistência. Ploft.

Uma pessoa chega para morar num apartamento onde já viveram diferentes famílias ao longo de vários anos. As paredes não têm ouvidos, dizem os mais velhos. Silenciosas, cobrem encanamentos e fios instalados no passado. Uma hora, um cano cede à pressão e a água vaza, mancha, estufa. "Pois bem, aconteceu, caiu na sua mão", ouve o recém-chegado. A causa pode ter sido um erro na escolha do material de construção, de cálculo, de execução do serviço ou simplesmente o tempo de uso. "Não importa, agora não tem mais jeito. É com você mesmo".

Demorei algum tempo para notar a questão das formas de heranças neste trabalho, pois comecei a pensá-lo a partir da ideia de escuta, mais especificamente da escuta de silêncios. Logo no começo me indagaram se uma noção mais amplamente discutida, a da memória, não deveria ser o enfoque aqui, no lugar da questão da herança. Mas, de algum modo, sabia que esse não era exatamente o tema.

A memória sobre como foram construídas aquelas paredes do apartamento, com quais materiais e técnicas, foi perdida depois de tanto tempo. No entanto, o esquecimento não é um vazio, um branco absoluto, limpo. É algo próximo ao "sumiço" dos brinquedos para as crianças, mais interessante porque deixa à mostra seus rastros. O esquecimento deixa marcas e resquícios para trás: do apagamento, do descolamento, da perda. Como esses resíduos têm materialidade, embora extremamente sutil, eles afetam as pessoas que os herdam - seja por sorte, azar, acaso, nascimento. 
O silêncio é como o esquecimento: ele também vai acumulando, juntando um pequeno bolo quase imperceptível, frágil mesmo. Anos de silêncio não são um vazio simplesmente. Eles afetam as pessoas que os herdam. Uma herança difusa, confundindo as hierarquias, ascendências e descendências. Contraditório em relação ao lugar comum da herança, pois as exatas origens e razões de ser, caso tenham existido, já estão irreparavelmente perdidas.

Talvez devesse abrir mão de escrever sobre formas tão mínimas de herança, se elas são incapazes de existir com a mesma força da memória, do lembrado ou daquilo que se elege para a exibição de um museu. Se são incapazes de existir com a mesma força do dito, do registrado e oficializado em papéis e documentos.

Porém, a frase grafitada na Lapa atravessa essa possibilidade e anuncia claramente o estado das coisas: "xeque-mate como no xadrez".

Isso aqui caiu na minha mão: silêncios acumulados ao longo de décadas que nos afetam não como memória, não como discurso articulado, mas como a água vazando lentamente numa parede da nossa casa. Podemos deixá-los como estão e ignorá-los, é claro.

Mas em algum lugar bem próximo esses silêncios estão descolando, caindo, agindo. Também é possível criar modos de escutá-los. 


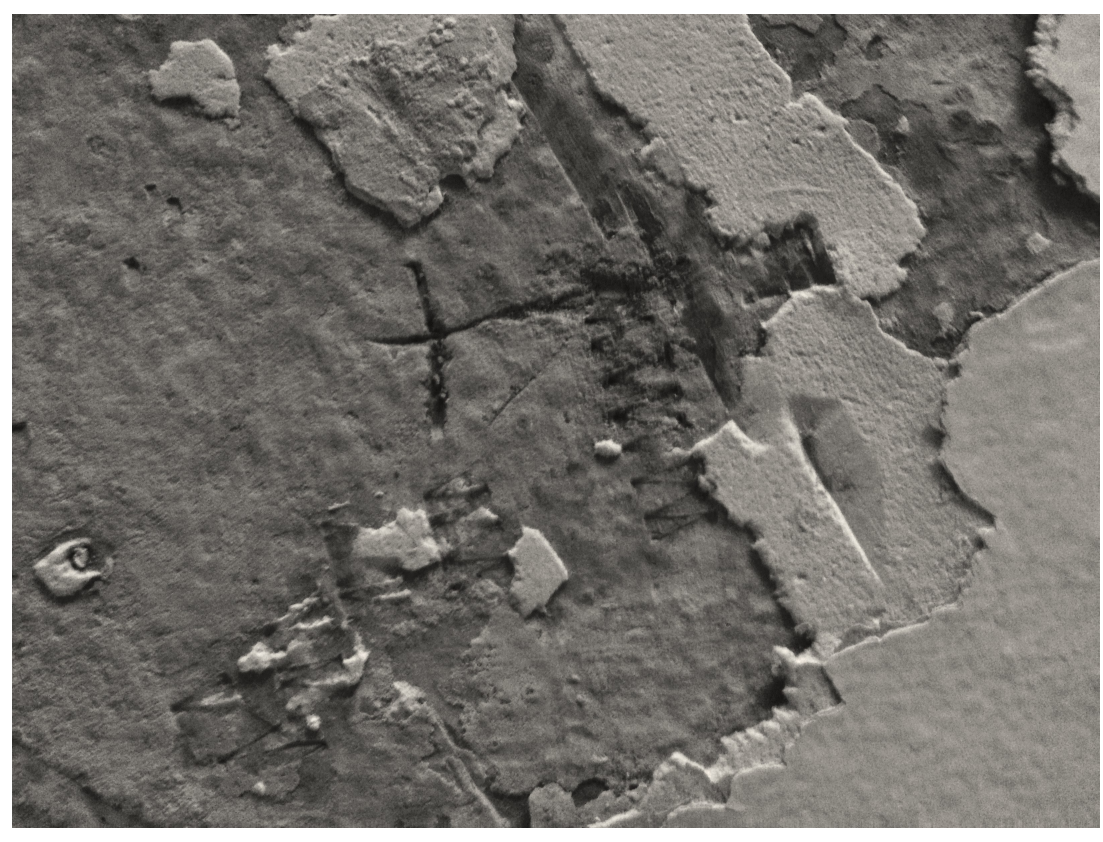

Rodapé

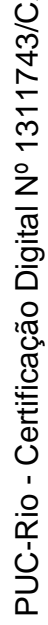




\section{4 \\ Perto do silêncio}

Conforme a noite chega, a menina vai deixando de falar. À meia-noite, está em silêncio. A voz se extingue na medida em que a possibilidade de ser ouvida se torna mais escassa. As portas estão se fechando para ela.

聞

Em japonês, o ideograma do verbo ouvir é formado pela combinação de outros dois: o de ouvido e o de portão. Imagem bidimensional: o ouvido emoldurado pelas duas portas altas. Ao contrário da boca, não tem dentes para se trancar. O portão se adianta, precisa barrar o acesso a essa abertura do corpo.

O ouvido se inclinando em direção à fresta já é um gesto de convite a passagens, alguma passagem.

Ele estaria a ponto de atravessar essas portas? Ou aguarda imóvel quem conseguir passar por elas?

Quem teria o privilégio de ser recebido pelo ranger das dobradiças, da pesada abertura das portas de madeira, para entrar e ter seus pleitos ouvidos pelo rei?

A menina está calada. Ela não teria a ousadia de socar esses portões, suas mãos não teriam forças suficientes - é o que dizem.

Sobra silêncio nessa menina. 


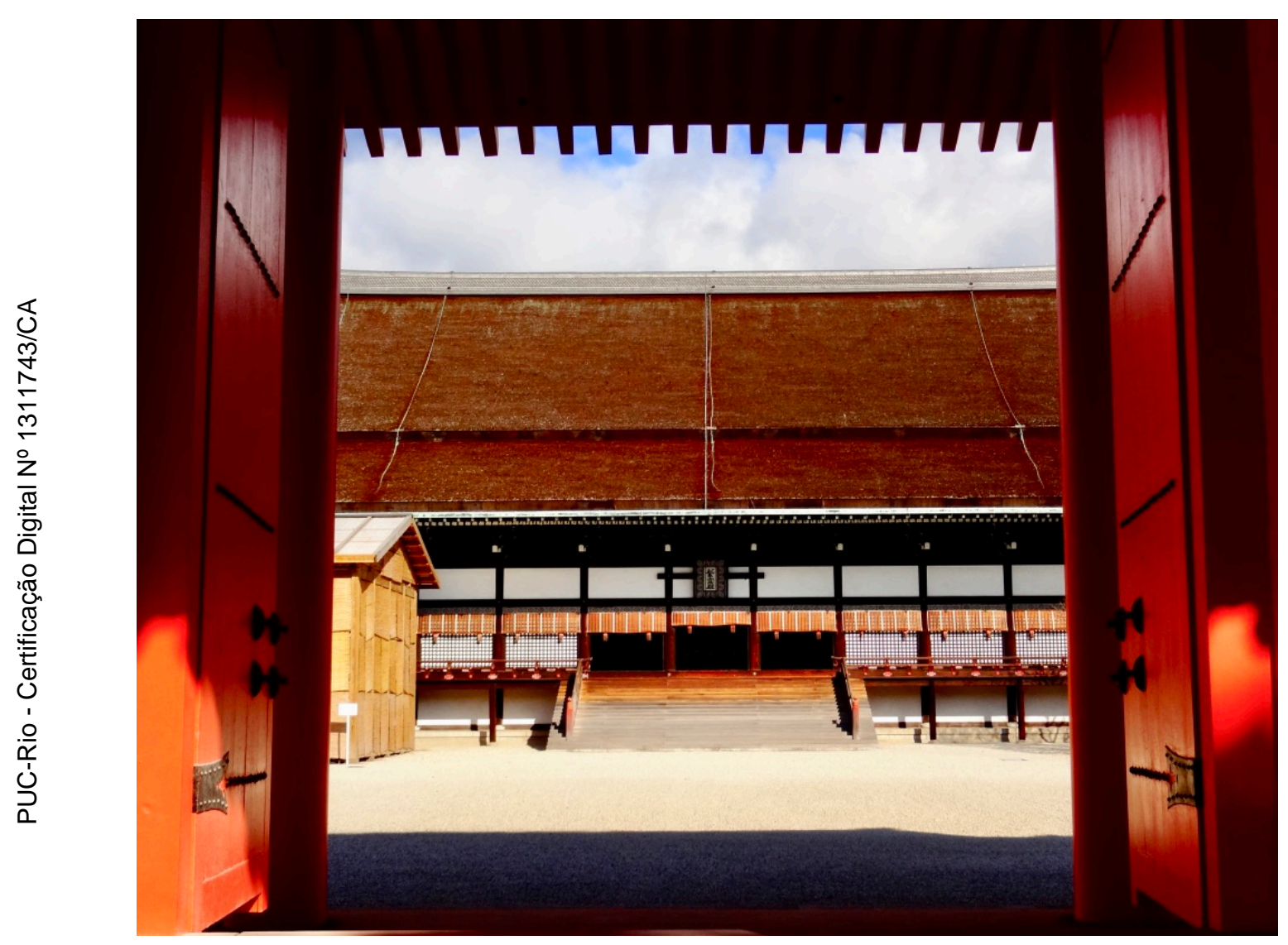

Fonte: Arquivo pessoal 
Inicialmente, pensei estar tratando de um vazio, da ausência de som. No entanto, quanto mais se aproxima, mais ruidoso fica o silêncio. Se houver concentração suficiente, percebe-se o quão barulhento pode se tornar.

Na tese de doutorado "John Cage e a poética do silêncio", Alberto Andrés Heller descreve a experiência que redefiniu as ideias do artista norte-americano sobre o silêncio, logo no começo dos anos 1950. Ao entrar na câmara anecoica da Universidade de Harvard, totalmente à prova de som, Cage ouviu seus batimentos cardíacos, sua circulação sanguínea e até seu sistema nervoso. "Silêncio nada mais é que um som tão suave (ou tão grave ou tão agudo) que mal o percebemos", diz Heller (2008, p.18). Para Cage, são os sons não escritos da música, pois mesmo a pausa na partitura indicada pelo compositor é repleta de outros sons, imprevistos e incontroláveis. Assim, como ressalta Heller, a poética do silêncio de Cage se baseia neste princípio: não há silêncio que não esteja prenhe de sons.

Adriana Sucena Maciel, na tese "ou aquilo a que chamamos arte", considera a experiência de Cage na câmera anecoica fundamental para seu entendimento do silêncio não como ausência de som, mas como o exato começo da possibilidade de escuta - aqueles instantes em que os ruídos baixam o tom, o volume, criando no corpo uma disposição para ouvir. O ruído não é entendido como interferência que interrompe o silêncio. Pelo contrário: é indissociável dele, da vida inclusive, pois há sempre um ruído a ser captado. O silêncio se dá trazendo para si os ruídos da vida. "Silêncio é ruído inerente ao corpo", afirma Maciel (2015, p. 44), apresentando, em seguida, a seguinte citação de Cage: "Thoreau said that sounds are bubbles on the surface of silence. They burst. The question is to know how many bubbles silence has on it." 2

\footnotetext{
2 Tradução livre minha: "Thoreau disse que os sons são bolhas na superfície do silêncio. Elas estouram. A questão é saber quantas bolhas há no silêncio."
} 
Assim como o som, o silêncio é imersão.

Penso num corpo boiando na água. Quando os pulmões se esvaziam, o peito afunda levemente. Os ouvidos mergulham. Na inspiração torna-se a ouvir o som no ar, as vozes lá fora.

O corpo vai oscilando, a escuta passa de uma dimensão a outra.

E depois volta.

O fio d'água corta os sentidos, separa percepções diferentes.

Corpo-boia sempre entre real e ficção, morte e vida, ar e água.

As bolhas se soltam dos movimentos do corpo entre fundo e superfície.

Penso na menina imersa no seu silêncio. Tão prenhe de sons prestes a estourar. Ela está sobrevivendo, resistindo à escassez de meios para ser ouvida. Grávida de ruídos e outras interferências sonoras.

A matéria mesma da negação, da submissão, da opressão... é furada, vazada por todos os lados. A clausura do silêncio imposto falha, pois seu material é poroso.

Bolhas rasgando a superfície, as paredes da sala, da cela. 
No artigo "Silencio, se rueda", Beatriz Ferrús enumera alguns modos de o silêncio ser entendido na sociedade: como homenagem ("faremos agora um minuto de silêncio); como ato de protesto (quando um acusado se recusa a reconhecer a legitimidade jurídica da sua condenação); como vocação (os religiosos que fazem voto de silêncio), como característica da personalidade (no seu extremo, o caso do escrivão Bartleby, personagem de um conto de Melville, que adota radicalmente a frase "I prefer not to" a ponto de enlouquecer o advogado com quem trabalha e romper com a lógica discursiva). O silêncio pode ser também uma escolha, uma necessidade de fugir de um mundo em que deixar a televisão ligada serve de alívio para a solidão.

No entanto, ressalta Ferrús, homens e mulheres foram posicionados histórica e culturalmente de maneira desigual diante do binômio palavra/silêncio:

\begin{abstract}
Desde la sentencia de San Pablo: 'las mujeres callen en la Iglesia' (I Corintios, 14, 34-35), pasando por la recomendación de Fray Luis en La perfecta casada, donde afirma que las mujeres 'han de guardar la casa y el silencio', o por el motivo pictórico, que llevó a comienzos de XVII a Marcos de Orozco a retratar a una monja con un candado en la boca, la asociación mujer y silencio ha sido continua a lo largo de los tiempos. (Ferrús, 2007, p. 12). ${ }^{3}$
\end{abstract}

Ao dever das mulheres de cuidar do lar, somava-se o de conter a própria boca, as opiniões próprias e as divergentes. Nesse contexto, embora em português calar-se e silenciar-se tenham sentidos muito próximos, é interessante observar as sutilezas de dois verbos a eles relacionados: tacere e silere - um tema discutido também no âmbito da psicanálise, por conta da relação clássica em consultório entre uma pessoa que fala e outra que escuta.

No artigo "Palavras do silêncio", João Batista Ferreira lembra a distinção feita por Jacques Lacan entre taceo, tacere, a suspensão de palavra, e sileo, silere, a ausência de voz, o silêncio da pulsão. Ferreira faz uma paralelo com a diferença entre palavra barrada e vazio de palavra: "No primeiro caso, a palavra pode ser

\footnotetext{
3 Tradução livre minha: "Desde a sentença de São Paulo: 'as mulheres se calem na Igreja', passando pela recomendação de Frei Luís em $A$ esposa perfeita, na qual afirma que as mulheres "têm de guardar a casa e o silêncio", ou pelo motivo pictórico, que levou Marcos de Orozco, nos princípios do século XVII, a retratar uma freira com um cadeado na boca, a associação entre mulher e silêncio tem sido contínua ao longo dos tempos".
} 
falada com a quebra do silêncio. No segundo, o silêncio pode falar como exclusão da palavra" (2009, p. 20-21).

Assim, pode se imaginar que as imposições da vida em sociedade não conseguem atuar efetivamente em todos os aspectos implicados no silêncio de alguém. Algo escapa ao controle. O silêncio vai além da palavra. Talvez o calar-se produza um resíduo de silenciar-se, ou, em outras palavras, calar-se crie acúmulos de silêncios que falam — seriam as consequências de abster-se voluntariamente da palavra.

Numa aula publicada em $O$ neutro (2003, p. 49-65), Roland Barthes comenta a "nuance interessante" entre tacere (silêncio verbal) e silere (tranquilidade, ausência de movimento e de ruído). Tacere, como silêncio da fala, marcava uma oposição ao silêncio de natureza ou de divindade, o silere que remeteria a uma espécie de virgindade intemporal das coisas, antes de nascerem ou depois de desaparecerem. Para Barthes (2003, p. 50), embora calar-se e silenciar tenham se tornado sinônimos em francês, há uma preponderância do sentido de tacere: "a natureza é de alguma forma sacrificada à fala: o silêncio só é da fala, a não ser poeticamente, arcaicamente: 'Tudo silenciava'”.

Quando o ajudante de direção bate a claquete no set de filmagem e grita "silêncio, gravando" — título do artigo de Beatriz Ferrús — chama-se algo do tacere, mas também resíduos da natureza do silere. "A ordem do discurso é suspensa, a palavra cessada inaugura uma nova lógica do real, a evocação ao ‘silêncio' atua como uma conjuração” (Ferrús, 2007, p. 11).

Um mundo é posto em silêncio (ruidoso) para que outro passe magicamente a existir. A fala se cala e nos aproximamos das coisas limítrofes, prestes a nascer ou a desaparecer. É nesse momento que Hamlet pronuncia as últimas palavras antes de morrer: "O resto é silêncio". 


\section{5}

\section{Zanshō no oto e Still hear the wound: projetos-relâmpago}

Um relâmpago

e o grito da garça

fundo no escuro

Matsuo Bashō

Luz e som cortam o céu, no mesmo instante, e logo desaparecem para sempre - o poeta... apenas esteve lá. Esse é um dos temas essenciais do haicai, forma de poesia surgida no Japão no século XVI e popularizada por Matsuo Bashō (1644-1694). É composto em três versos, o primeiro com cinco sílabas, o segundo com sete e o último com cinco.

Como afirma Octavio Paz, em Signos em rotação, a luz do relâmpago e o grito da garça no haicai de Bashō são duas realidades inseparáveis que, contudo, jamais se fundem. Já em $O$ império dos signos, Roland Barthes (2007, p. 99) analisa a concisão do haicai: não se trata de um pensamento rico reduzido numa forma breve, mas de um acontecimento breve descoberto, de golpe, na sua forma justa. $^{4}$

Duas realidades, luz e som; dois acontecimentos inseparáveis que jamais se fundem. No haicai, a própria poesia se escreve acercando-se do acontecimento, sempre acentuando sua imprevisibilidade. Em A preparação do romance, Barthes define da seguinte maneira a noção de incidente no haicai: "aquilo que cai, aquilo que produz uma dobra, e, no entanto, não é outra coisa" (2005, p. 115, grifo meu).

\footnotetext{
${ }^{4}$ No segundo capítulo da dissertação de mestrado intitulada Said e Barthes: Orientes possiveis nas escritas de si (Aibe, 2013), dedico-me ao tema das relações entre textos de Barthes e o haicai.
} 
Essa ideia de queda - uma queda poética — também surge quando ele (2005, p. 108, grifo meu) escreve sobre a contingência no haicai: "aquilo que caiu uma vez, num instante único, sobre o sujeito: uma voz, um ruído (a contingência capta o perecível, o mortal)". O acontecimento fortuito, mas de incisão precisa no tempo, é aquilo que cai, apenas uma vez, naquele instante, produzindo uma dobra — traços sublinhados no haicai por Barthes.

Parece-me especialmente interessante aproximar essa ideia de queda poética — como a queda de um relâmpago do céu, num acontecimento-golpe — de outra forma breve de escrita: o ensaio.

Neste caso, penso mais especificamente em golpes, cortes, no peso da lâmina na superfície. Isto o ensaio pode produzir: pensamentos-corte. Não necessariamente permanentes, pois, dependendo da situação, as fendas não permanecem estáveis num ponto.

Creio ser essa uma possibilidade para se escrever sobre o tema da escuta de silêncios herdados: não tentar condensar pensamentos ricos em ensaios breves, mas tentar encontrar uma forma justa, numa cortada, para pensamentos breves, para flashes de ideias.

É curioso que meu encontro com este tema também tenha acontecido de um golpe só, em março de 2015, ao me deparar com uma fotografia da série Herança Virtual $^{5}$ (2008), de Yamashiro Chikako, artista japonesa integrante do projeto Zanshō no oto: ajia, seiji, aato no mirai e, ${ }^{6}$ cujos desdobramentos nos Estados Unidos foram intitulados como Still Hear the Wound: Toward an Asia, Politics, and Art to Come 7 . Na ocasião, eu estava pesquisando na Universidade de Cornell, com apoio de uma bolsa sanduíche concedida pela CAPES e pela Comissão Fulbright.

Iniciado em 2006 e organizado pela coreana Lee Chonghwa, professora da Universidade Seikei, em Tóquio, o projeto colaborativo Zanshō no oto reúne artistas e pesquisadores em torno da tentativa de reimaginar articulações e

\footnotetext{
${ }^{5}$ Traduzido em inglês como Virtual Inheritance, o título original do trabalho é バーチャル継承.

${ }^{6}$ No original em japonês: 残傷の音 :「アジア・政治・アート」の未来へ.

${ }^{7}$ Tradução livre minha: "Ainda ouvir a ferida: rumo a uma Ásia, política e arte porvir".
} 
possibilidades para os termos “Ásia", "política" e "arte”, criando modos de ouvir os murmúrios de pessoas cujas vidas e mortes aconteceram nos bastidores da política e da história da Ásia Oriental ${ }^{8}$ (Jennison, 2015).

Em 2009, foi publicado no Japão o livro de mesmo título, ${ }^{9}$ com artigos e trabalhos artísticos dos participantes dos encontros e seminários promovidos por Lee Chonghwa - a edição inclui ainda um DVD com fotografias, performances e entrevistas com artistas do grupo. A partir da colaboração com a professora Rebecca Jennison, da Universidade Seika de Quioto, a professora Brett de Bary, dos departamentos de Estudos Asiáticos e Literatura Comparada da Universidade de Cornell, instigou o debate das questões de Zanshō no oto nos Estados Unidos, especialmente a partir do workshop multimídia 'Still Hear the Wound': Art, Affect, and Post-Colonial Memory in Japan, ${ }^{10}$ realizado em 6 de março de 2015, no campus da universidade, e da seleção e tradução dos textos de Zanshō no oto para a publicação do livro Still Hear the Wound: Toward an Asia, Politics, and Art to Come (Lee, 2015a). ${ }^{11}$ As provocações e reflexões de Still Hear the Wound, tanto o workshop quanto o livro, inspiraram esta tese.

Uma das primeiras perguntas instigadas ainda sussurra: como conseguimos ouvir feridas que não vemos marcadas na nossa pele? Sem jamais serem totalmente compreendidas, elas continuam a "murmurar" no presente — uma noção cara ao pensamento de Lee Chonghwa.

Conforme explicam Jennison e Brett (2015), o próprio título Zanshō no oto revela a estratégia poética de Lee, que inventou uma composição estranha aos dicionários de japonês ao juntar o ideograma zan ${ }^{12}$, ligado a "resto", "sobra" e

\footnotetext{
${ }^{8}$ No original em inglês, é utilizado o termo "East Asia" (Jennison, 2015). De acordo com o sistema de classificação da Organização das Nações Unidas, a região da Ásia Oriental compreende os seguintes países: China (incluindo as regiões administrativas especiais de Hong Kong e Macau), República Democrática da Coreia, Japão, Mongólia e República da Coreia.

${ }^{9}$ Lee, 2009.

10 Tradução literal: “Ainda ouvir a ferida: arte, afeto e memória pós-colonial no Japão”.

${ }^{11}$ A edição em inglês de Zanshō no oto foi comercializada a partir de 2016. Graças à colaboração da professora Brett de Bary, em maio de 2015 pude ter acesso à tradução provisória da maioria dos capítulos do livro. Sem esse material cedido generosamente por ela, teria sido impossível realizar esta pesquisa de doutorado dentro do tempo previsto.

12 残
} 
ao verbo "permanecer", e o ideograma $s h \bar{o}^{13}$ (também lido como kizu), de "ferida" ou "cicatriz". Assim, o neologismo zanshō significa algo como "feridas que ainda permanecem" - no contexto desta tese, aposto mais em outra tradução possível: "feridas que ainda restam, sobram".

Para Jennison (2015, p. xx), ao relacionar o novo composto zanshō e o ideograma para "som" - em japonês, oto ${ }^{14}$ — o título do projeto de Lee transmite um "sentido visceral dos sons/vibrações que ainda permanecem e ressoam". Em uma palestra dada em 2014, na 14 ${ }^{\text {a }}$ Conferência Internacional da Associação Europeia para Estudos Japoneses, Brett de Bary traduziu Zanshō no oto como "Resonant Scars" (literalmente, "cicatrizes ressonantes").

Para entender um pouco mais a questão do murmúrio em uma obra que valoriza os entrelaçamentos de pensamento e sonoridades poéticas, como faz a de Lee Chonghwa, cabe mencionar sua obra mais conhecida, Tsubuyaki no seiji shisō (Murmurs as political thought ${ }^{15}$ ), ainda sem tradução para o inglês. De acordo com Jennison (2015, p. xxi), Lee descreve a forma e o estilo híbrido dos ensaios desse livro como uma "montagem de murmúrios", cujo objetivo foi criar novas formas de ver, ouvir e dialogar com vítimas de traumas da guerra do Pacífico (1931-1945), ${ }^{16}$ sobretudo acolhendo seus sentimentos.

Tsubuyaki foi publicado em 1998, quando estava se tornando mais acirrado na sociedade japonesa o debate sobre memórias da guerra e reconciliação a respeito das "mulheres de conforto militar", termo que atenua a cruel realidade vivida por milhares de mulheres forçadas a servir como escravas sexuais para as

\footnotetext{
13 傷

14 音

15 Tradução livre minha: Murmúrios como pensamento político.

${ }^{16}$ A maioria das referências bibliográficas desta pesquisa utilizam "Pacific War" ou "Asia Pacific War" para se referir a fatos que, no Brasil, geralmente são englobados pelo termo "Segunda Guerra Mundial". Ao longo deste trabalho, adotei o termo "Guerra do Pacífico", considerando seu marco inicial a invasão japonesa da Manchúria, na China, em 1931. Muitos historiadores, especialmente de perspectiva norte-americana, consideram o ataque de Pearl Harbor como o início da Guerra do Pacífico. Como não há um consenso, preferi reforçar que já nos anos 1930 estava em curso a política militar japonesa de expansão colonial na Ásia.
} 
tropas imperiais japonesas. ${ }^{17}$ Segundo historiadores, aproximadamente $200 \mathrm{mil}$ mulheres foram escravizadas até 1945, sendo a maioria delas coreana de origem pobre. Na época, o Japão Imperial impunha controle colonial sobre a Coreia, oficialmente anexada em 1910, e investia na expansão de seu poderio militar na Ásia, ocupando territórios como Cingapura, Filipinas, Indonésia, Tailândia, Taiwan e Vietnã.

Nascida poucos anos depois da guerra, na ilha Jeju, na Coreia do Sul, filha de dissidentes políticos, Lee Chonghwa publicou em Tsubuyaki uma conversa com a artista Shimada Yoshiko, na qual ela comenta a experiência de discutir o tema das "mulheres de conforto" com alunos universitários no Japão. Para se referir a essas mulheres, ela deu preferência ao termo harumoni, ${ }^{18}$ que vem da palavra coreana para avó, criticando o termo mais usado no Japão (o formal “exmulheres de conforto"). Durante uma palestra no workshop "Still Hear the Wound': Art, Affect, and Post-Colonial Memory in Japan, Lee (2015b) enfatizou seu desejo de tentar ouvir as harumoni e imaginar suas vidas.

Para Mizutamari Mayumi (2015), ${ }^{19}$ professora da Universidade de Hokkaido também participante do workshop, Lee oferece em Tsubuyaki uma detalhada consideração tanto sobre os modos de se narrar memórias traumáticas quanto sobre a atitude a ser assumida pelos ouvintes desses relatos, criticando enfaticamente a interpretação ou conceituação do trauma vivido por outra pessoa. $\mathrm{Na}$ opinião de Mizutamari, Lee rejeita pares opositivos como "coreanos versus japoneses" ou "opressor versus oprimido", por considerar o significado da memória do sobrevivente inesgotável em categorias políticas. Além disso, Lee chama a atenção para o fato de coisas ainda não ditas serem uma condição indispensável para a sobrevivência de quem decide falar. Para Mizutamari, este é o motivo principal do apelo de Lee àqueles dedicados à tarefa de aceitar os

${ }^{17}$ É raro encontrar artigos e livros acadêmicos em português sobre o problema das "mulheres de conforto". No artigo "As 'mulheres de conforto' da Guerra do Pacífico", Julia Yuri Okamoto (2013) faz um resumo do contexto histórico e das principais questões éticas e políticas a partir de uma bibliografia em inglês.

18 ハルモニ

${ }^{19}$ Durante o workshop 'Still Hear the Wound': Art, Affect, and Post-Colonial Memory in Japan, Mizutamari Mayumi leu um texto em japonês que incluía os comentários citados acima, traduzidos por ela para o inglês. 
sobreviventes e seus modos de vida: um pedido baseado na busca da compreensão não somente por meio do intelecto, mas também do corpo e dos sentimentos.

Feridas são cortes ressonantes, murmurantes nos corpos e nas lembranças dos sobreviventes. Apesar de sua natureza delicada, ou talvez exatamente por ela, murmúrios não se extinguem com a morte das pessoas que os carregaram. Continuam soando baixo, fora da cena principal, nos bastidores dos acontecimentos históricos.

Pequenos cortes de faca que se fazem ouvir e sentir quando nos aproximamos do silêncio.

Dentro da câmara anecoica de John Cage, são estrondosos como o relâmpago caindo do céu, como o grito da garça no escuro da noite. 


\section{6 Herança e desvio}

O rosto da artista é suavemente iluminado na fotografia. Nariz, bochechas e boca são destacados pela luz vinda de cima, quase divina. Ela está coberta por abraços de idosos — os braços femininos podem ser identificados pelos anéis dourados nos dedos, usados em duplas na mão direita.

A mão de uma das senhoras divide horizontalmente a imagem — ela aperta a bochecha de Yamashiro Chikako. Seus lábios brilham em um tom vermelho, jovial, em contraste com as peles cheias de rugas, manchas, vincos e veias tocando a artista.

Além do rosto de Yamashiro, a única face à mostra na foto é a de uma senhora atrás dela. Não é possível ver seus olhos, apenas seu nariz e parte das bochechas e boca. A textura e cor de sua pele são de alguém excessivamente velho. Ela envolve a artista com os braços e repousa a mão sobre sua testa, deixando à mostra uma parte da franja.

Os braços se misturam e se sobrepõem ao tocá-la, escondendo os contornos do seu corpo. Yamashiro poderia facilmente ser confundida com uma criança, uma menina, embora tivesse mais de 30 anos quando a foto foi tirada.

Através das peles em contato, são evidenciados simultaneamente simbioses e abismos entre as gerações. O que, afinal, o toque poderia transmitir de uma geração para outra?

A cena é de ternura, como a imagem de uma criança sendo afagada? $\mathrm{Ou}$ também passa uma espécie de sufocamento, pela quantidade de mãos envelhecidas envolvendo o corpo de Yamashiro?

A artista parece reagir com sua mão voltada para trás, encostando no braço da idosa que a abraça. Seria um gesto de acolhimento? De contenção diante dos abraços dos velhos? 
Acalentar, sufocar, acolher, conter... É tênue nesta imagem a linha separando um gesto do outro.

A fotografia faz parte da série Herança Virtual (2008), de Yamashiro Chikako, integrante dos projetos Zanshō no oto e Still Hear the Wound, e está disponível no blog da artista japonesa. ${ }^{20}$ 


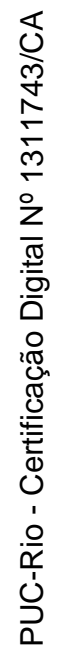

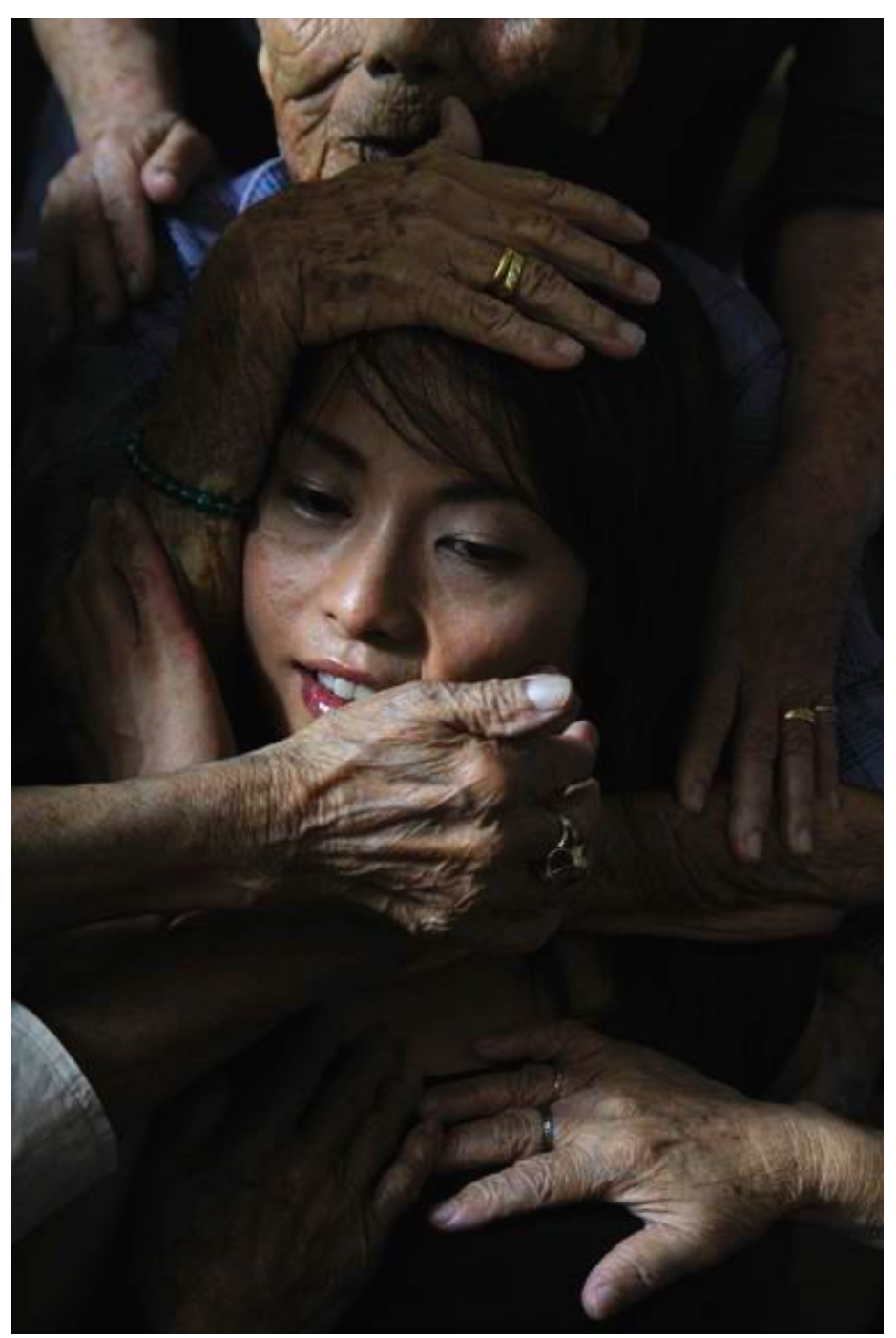


Observar a imagem de Yamashiro despertou alguns pensamentos-golpe.

O primeiro: é preciso escutar esta fotografia. Ver com os ouvidos. E também educar os olhos a escutarem.

O segundo: é interessante reimaginar um gesto familiar e até corriqueiro, o de ouvir desviando o olhar. Quando se ouve algo enquanto se rabisca desenhos ou anotações soltas, por exemplo. À primeira vista, é uma atitude distraída, até descuidada. Certas vezes, no entanto, ao criar desvios para a atenção percorrer e ajudar a focá-la em uma outra nota, possibilita uma escuta mais aguçada. Em outras palavras, abre espaço para a escuta, tantas vezes esmagada na cultura visual em que vivemos.

Descola-se o contato visual, mas se mantém o toque, aquele do ouvido com a coisa, um toque outro - e quem sabe assim será possível perceber murmúrios afastados, num primeiro lance inexistentes na imagem?

Terceiro pensamento-golpe, uma sequência de perguntas: é possível ouvir o silêncio na imagem? É possível sentir em uma imagem silêncios herdados de outras pessoas, outras gerações, outros tempos? Seria esse um dos modos de notar a permanência de silêncios acumulados, sua suave materialidade, ainda hoje?

A fotografia de Yamashiro sussurra - em voz realmente baixa experiências silenciadas, indesejadas, de uma época distante no tempo. Por alguma razão, encontraram formas de sobrevivência.

Algo incômodo do passado perpassa silenciosamente entre as gerações, quieto e rumorejante como um riozinho à beira de desaparecer para sempre. 


\section{'Nossos japoneses'}

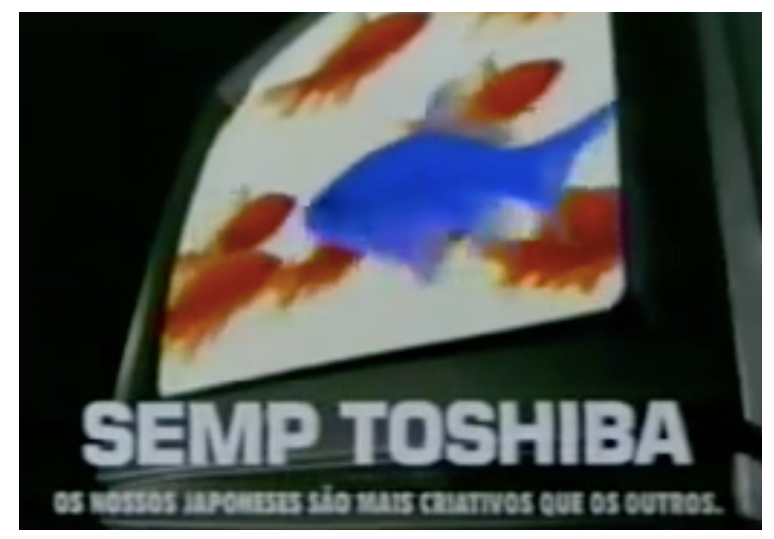

Fonte: Reprodução YouTube

NESTE RÉVEILLN, OS NOSSOS JAPONESES RESOLVERAM

DAR GARANTIA ATE 0 ANO 2000 PARA TODOS OS TELEVISORES.

MAS SEJA RÁPIDO, ANTES QUE PASSE O EFETTO DO SAQUÊ.

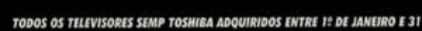

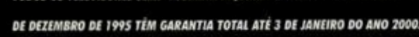

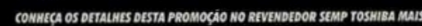

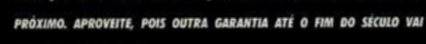
OEMORaR Para aparaccer.

SAMP TOSHIBA.

os Dulcos Tis

com Gapanila TORA.

Ant: 0 AN10 2000.

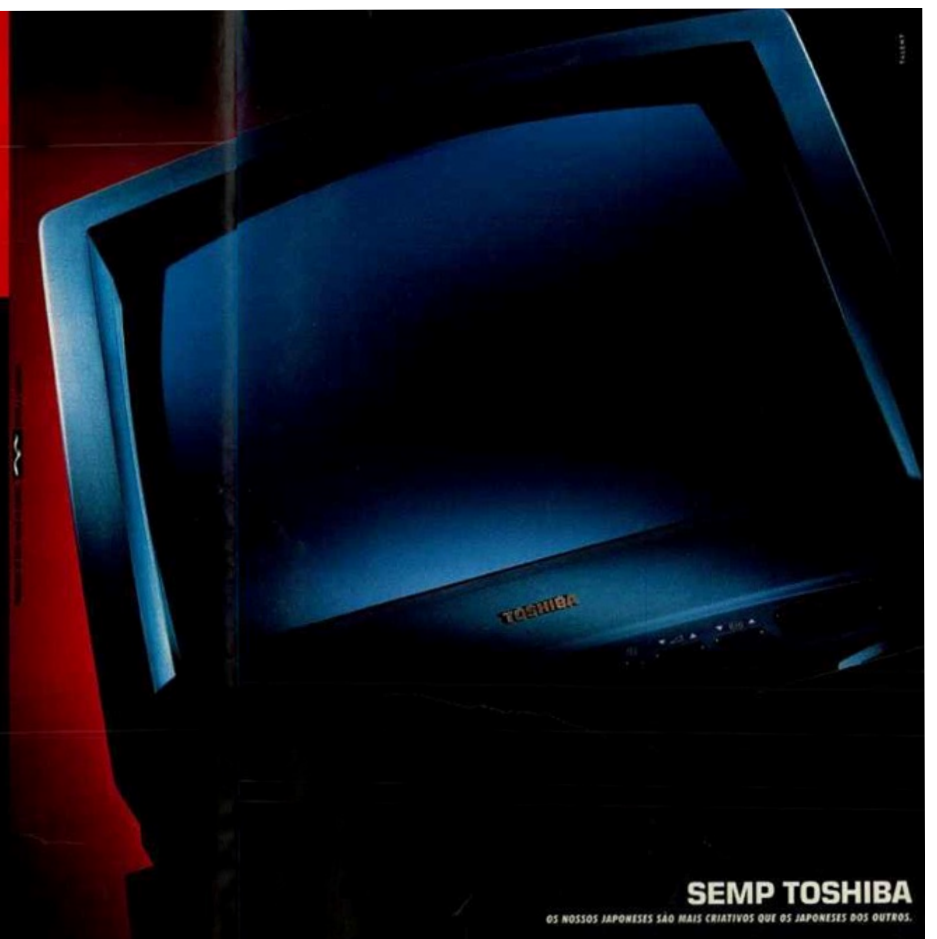

Fonte: Site Propaganda em Revista. Anúncio publicado pela revista Veja em janeiro de 1995 
Projeções de imagens, nomes, instituições e países, repetidas e reiteradas apressadamente ao longo de anos. Quando se consolidam em ângulos determinados, instigam lembranças e reflexões muito similares, expostas ao desgaste, seja em relação a um autor renomado ou à cultura de uma nação.

O Japão não poderia ser considerado uma dessas instituições aparentemente consolidadas? Uma ilha, um arquipélago, pequeno, populoso, unido, coeso... Supostamente mais homogêneo do que imaginamos o Brasil, por conta da distância, do estereótipo?

No prólogo do livro Discontented Diaspora: Japanese Brazilians and the Meanings of Ethnic Militancy, 1960-1980, o historiador norte-americano Jeffrey Lesser (2007) lembra a campanha publicitária criada no começo da década de 1990 para a marca de eletrodomésticos Semp Toshiba (resultado da fusão entre empresa brasileira Semp Rádio e Televisão e a japonesa Toshiba Corporation), cujo slogan foi usado por cerca de dez anos. Para Lesser, o bordão "Os nossos japoneses são mais criativos que os japoneses dos outros" foi não apenas uma estratégia de marketing, mas sobretudo um reflexo da complexa relação entre Brasil e Japão ligada à construção da identidade nacional de mais de um milhão de brasileiros descendentes de japoneses.

Por que dizer "nossos japoneses"? Além de destacar a criatividade, qualidade atribuída no imaginário popular brasileiro a seu próprio país, o slogan supõe a competência de todos os japoneses quando se trata de aparelhos tecnológicos, anunciando a característica diferente dos "nossos", da Semp Toshiba, da mistura de Brasil com Japão. Em outras palavras, vende-se a tecnologia já esperada dos japoneses somada ao inusitado encontro com a criatividade brasileira. Por extensão, os "japoneses dos outros" seriam os das outras marcas, dos outros países, desprovidos portanto da "brasilidade" e de sua criatividade singular.

Veiculada em 1995, uma das peças da campanha publicitária anunciava televisores da marca como os únicos com garantia total "até 3 de janeiro do ano 2000". A versão para revistas traz a imagem de um aparelho se sobressaindo em um fundo vermelho, ao lado da frase: "Você pode confiar no controle de qualidade 
de um povo que come peixe cru". Ao buscar, com humor, um viés positivo para esse aspecto da culinária japonesa, a empresa demonstra o estranhamento em relação ao hábito de se comer carne de peixe crua e faz generalizações - o comentário antes de ser transformado pela linguagem publicitária poderia ser algo mais ou menos assim: "estamos falando de um povo que come peixe cru, algo realmente esquisito, mas ao menos isso significa que eles são muito rigorosos com a higiene!".

Em um comercial para TV, ainda sobre aparelhos com longa garantia, uma mulher entra na loja de consertos: "Moço, minha tevê quebrou e eu trouxe para consertar". O atendente, de aparência oriental, rapidamente se espanta ao ver que se trata de uma "Semp Toshiba" e chama os demais funcionários, entre eles um tal de "Akira". Como são convocados até o "avô" e os vizinhos, o balcão logo fica cheio de gente curiosa diante daquela raridade: uma tevê japonesa pifada. Com excessão da cliente, todos falam com sotaque. "Ô, quebrô non, pilha tá contrário!", diz finalmente o atendente, após verificar o controle remoto. Em seguida, o locutor avisa: "Só a Semp Toshiba dá até 50 meses de garantia em tevês sem cobrar a mais por isso. Nossos japoneses estão mais criativos que os outros". Um coro finaliza: "Hai!" — “sim” em japonês. Moral da história, suponho: a criatividade singular dos "nossos japoneses" neste caso é oferecer a melhor oferta possível para os consumidores. Afinal, de acordo com a lógica explícita na campanha, qualquer produto de uma empresa japonesa já seria à prova de defeitos.

Outra peça para TV festeja o encontro com o Brasil. Os “japoneses” estão vestidos com quimonos em tons de laranja e lilás, com uma faixa branca amarrada na testa, recebendo comandos incompreensíveis de um líder. Eles correm de um lado para outro e, depois de se organizar em fileiras, levantam os braços juntos, gritando "hai!". De repente, há um close em um tambor e, quando o enquadramento abre, todos começam a dançar em ritmo de carnaval.

Ao apelar para uma espécie de exotismo nipo-brasileiro, incluindo menções ao peixe cru e ao saquê, a campanha promove familiaridade sem abrir mão de uma distância bem estabelecida entre nós e os "nossos japoneses". O ditado 
publicitário insinua: os japoneses e sua tecnologia estão logo ali ao nosso alcance, em qualquer equipamento produzido por eles - só a nossa criatividade "brasileira" quebra essa mesmice, e gera algo novo, um "diferencial" do produto e da maneira de os consumidores se relacionarem com ele. Nesse contexto, muitos comerciais da campanha na TV terminam com a cena de um único peixe azul nadando em um mar de peixes dourados, de uma espécie também conhecida no Brasil como peixe japonês.

Assim, uma característica básica atribuída implicitamente aos japoneses pela estratégia de marketing da Semp Toshiba é a dificuldade em distingui-los. Sem a inventividade brasileira, eles seriam todos iguais aos "japoneses dos outros".

O lado talvez mais perverso dessa lógica surge em mais um comercial para a TV: um rapaz de cabeça raspada, vestindo uma túnica, caminha entre muitas velas. Ele vai ao encontro de um mestre (espiritual?) sentado com os olhos semicerrados, grotescamente cinzas.

Segue um diálogo com vozes típicas de dubladores de filmes de TV:

"Mestre?"

"Sim, filho?"

"Não compreendo. Por que os japoneses da Semp Toshiba são mais criativos que nós?"

"Porque nós somos chineses. Sua anta."

O bordão "Os nossos japoneses são mais criativos que os japoneses dos outros" acentua os lugares comuns - como muitas propaganda fazem sem grandes pudores - , porém não deixa de insinuar uma certa zona de "conforto" para os descendentes de japoneses no Brasil. Uma oferta maliciosa e triste, sedutora se não houver reflexão: vocês são todos iguais, sim, mas de algum modo também igualmente melhores (do que os chineses, os coreanos, os demais “orientais", e, inclusive, do que os tais “japoneses dos outros"). Nesse contexto, é necessário indagar até que ponto as indústrias da publicidade e da mídia deixam 
de apenas propagar o senso comum e passam a contribuir fartamente para sua produção.

E se quisermos ir além das molduras desses estereótipos, das ideias já circulantes sobre os "nossos japoneses" e os "japoneses dos outros"... com o que poderíamos nos deparar? O que está calado nas ideias divulgadas midiaticamente a respeito desses temas, seja nos meios tradicionais, nas redes sociais ou nos novos modos de interações entre pessoas, produtos e empresas via internet?

Nesse contexto de uma suposta igualdade ou impossibilidade de diferenciar os japoneses, a ilha de Okinawa, localizada no extremo sul do Japão, é um problema-chave, que ainda nos impele a repensar modos de entender e apreciar a riqueza e a complexidade das heranças culturais. 


\section{8 \\ 'Uma praia bonita' - parte 1}

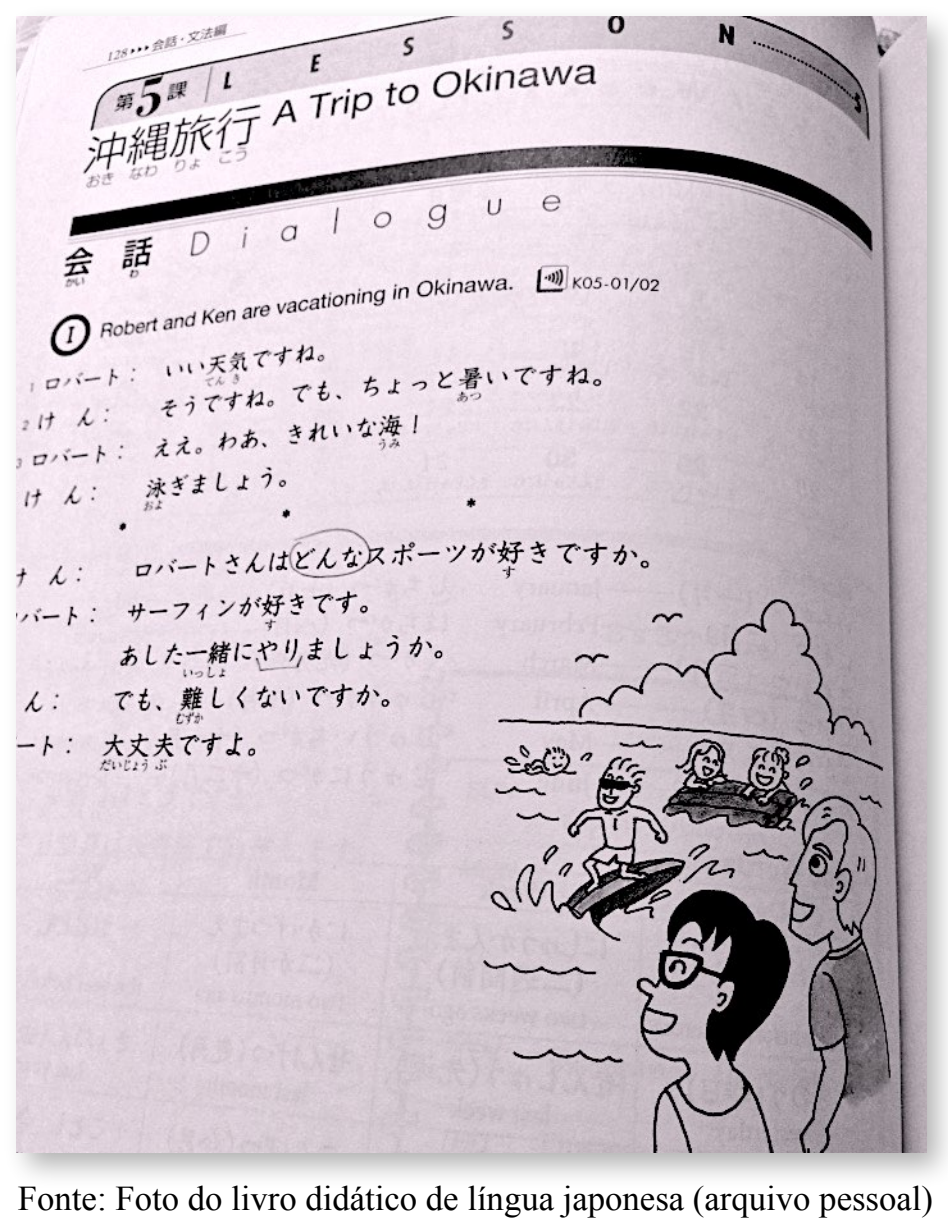


O tema da pesquisa eram as contradições entre o passado e presente de Okinawa. O sucesso como destino turístico obscurecendo ainda mais as feridas silenciadas por décadas. Para me aproximar desse assunto, decidi observar uma imagem entre a profusão de vídeos, textos e fotografias mostrando as maravilhas naturais da ilha japonesa, a partir de um critério de seleção simples: digitar a palavra "Okinawa" na ferramenta de busca por imagens do Google.

No dia 15 de novembro de 2015, o primeiro resultado mostrava uma praia belíssima, de águas transparentes, localizada numa estreita península. O fundo azul do oceano se mescla com as cores mais esverdeadas perto da areia, também muito clara. $\mathrm{Na}$ imagem área, vê-se quadras esportivas, uma delas de tênis, a poucos metros da praia. Um hotel de luxo, desses que poderiam ter sido construídos em Miami, Cancún ou no litoral brasileiro, surge enorme no final da península - praticamente uma muralha branca feita de quartos com vista para o mar.

A imagem em questão foi publicada do site da Expedia, empresa internacional cujo carro-chefe é sua agência de turismo online. O tom festivo da descrição da foto contrastou mais ainda com temas que pouco antes eu havia pesquisado, especialmente as implicações atuais do passado da ilha de Okinawa na Guerra do Pacífico. "Visite esta ilha tropical no sul do Japão", "relaxe em suas belas praias", dizia o anúncio. Ao falar dos atrativos, juntando as belezas do cenário natural, os esportes radicais na água e os castelos históricos dos "antigos senhores de Okinawa", o texto decretava: "é um paraíso tropical sedutor com um passado fascinante".

Quais são as leituras possíveis desse passado fascinante?

Quando conheci os projetos Zanshō no oto e Still Hear the Wound, durante um workshop na universidade de Cornell, nos Estados Unidos, eu tinha voltado a 
estudar japonês, depois de muitos anos. A turma era composta principalmente por alunos da graduação, a maioria deles nascidos na Ásia ou descendentes de chineses, coreanos ou vietnamitas. Jovens entre 18 e 20 anos, eles aprendiam rapidamente a gramática, a escrita, a fonética. Muitos consideravam aquela a disciplina mais fácil de sua grade curricular e diziam ter escolhido estudar a língua pelo interesse por música pop japonesa e animes (como são conhecidas as animações produzidas no Japão).

Logo nas primeiras semanas do curso chegamos à lição 5, sobre adjetivos. Elaborado especificamente para falantes nativos de inglês, o livro didático tentava reproduzir a experiência de um aluno de graduação morando no Japão para estudar a língua. Naquele ponto, o personagem Robaato-san (Sr. Robert) tinha feito amizade com um estudante japonês e eles estavam fazendo a primeira viagem juntos. Uma viagem a Okinawa.

No diálogo inicial da lição, depois de duas frases sobre o tempo quente, Robaato-san vira-se para o amigo e exclama: "waa, kireina umi”. ${ }^{21}$ Literalmente, quer dizer: "uau, um mar bonito!". A meu ver, em português soaria mais natural a tradução “uma praia bonita!", ou mesmo “que praia bonita!”.

De todo modo, embora se trate de um exemplo bastante pontual, achei curioso verificar como a construção de imaginário se dá em pequenas coisas como essa. Uma construção pedagógica (não só linguística, mas de aspectos amplos, para além do contexto do livro didático) na escolha de Okinawa para a lição sobre adjetivos e como destino de passeio dos personagens.

$\mathrm{Na}$ perspectiva do meu projeto pessoal de estudos (e quem sabe somente nesta perspectiva), faziam sentido outros cruzamentos entre a pesquisa para a tese e os detalhes da lição 5. Um deles diz respeito ao funcionamento dos adjetivos em japonês: nunca apresentam flexão de gênero, mas alguns se comportam como substantivos (é o caso de kirei). Outros são conjugados como verbos: no presente e no passado, em afirmação e em negação. Esse caráter gramaticalmente "mutante" desafia minha concepção dos adjetivos, baseada em aulas de português de muitos anos atrás: passivos e apêndices dos substantivos que, eles sim, passam

21 わあ、きれいな海! 
a "possuir" determinada característica. As aulas de redação de jornalismo também me ensinaram a evitá-los ao máximo, pois seriam imprecisos e pouco "informativos" de fato.

Do mesmo modo, vejo uma correspondência entre essa concepção e as primeiras impressões mais comuns sobre Okinawa. Afinal, o mar bonito, a praia bonita, o "paraíso tropical sedutor com um passado fascinante" não é tão passivo quanto pode aparentar. De maneira similar aos adjetivos, pode se tornar sujeito da frase, e do núcleo da oração praticar uma ação, hoje, ontem, deslocando no tempo. Afirmar ou negar sem precisar do auxílio de um verbo.

Outro cruzamento sutil neste contexto é o segundo objetivo da lição 5: ensinar uma conjugação verbal equivalente ao "let's" do inglês. "Oyogimashou", 22 "vamos nadar", diz o amigo japonês de Robaato-san. Um convite a fazermos juntos alguma coisa.

Pensando e sentindo os projetos Zanshō no oto e Still Hear the Wound e os trabalhos dos artistas que participam deles, entre eles Yamashiro Chikako, não posso deixar de considerar esta uma feliz coincidência, pois eles ressaltam a necessidade de uma construção coletiva. A meu ver, uma escuta coletiva do passado e do presente.

22 泳ぎましょう 


\section{9 \\ 'Uma praia bonita' - parte 2}

Os ideogramas de "mar aberto" e "corda".

Oki. Nawa.

Em japonês: 沖縄. Okinawa.

O território da ilha é em forma de uma corda não contínua lançada no meio do oceano - na verdade, um arquipélago de várias ilhas, maiores e menores.

Segmentos de corda sem nada por perto.

Observação: hífen longo é também uma pequena corda lançada no texto.

Quando a artista Yamashiro Chikako nasceu, em 1976, a prefeitura $^{23}$ de Okinawa havia retornado recentemente ao controle japonês, após 27 anos sob ocupação norte-americana. Pesquisadores e críticos usam com frequência o termo "reversão" para se referir a esse momento histórico, pois a palavra está no título do acordo assinado em 1971 entre Estados Unidos e Japão. Se, certamente, não se trata da reversão ou do retorno à situação anterior à Guerra do Pacífico, algo impossível, tampouco essa palavra descreve confortavelmente a relação do governo japonês com a região. Até hoje, cerca de $75 \%$ das bases militares dos

23 Prefeitura equivale a um estado no Brasil. Em português, também se diz "províncias" em referência às prefeituras japonesas. Em japonês, há quatro tipos de prefeituras, abarcados pela expressão 都道府県 (to•dō•fu・ken). Okinawa é um “ken” (県). 
EUA no Japão operam em Okinawa, ocupando aproximadamente 20\% de sua ilha principal (Jennison, 2014; Pajon, 2010; e Reynolds; Sharp, 2015).

Desde o fim da guerra, quando o Japão renunciou ao direito de recorrer a confrontos armados e se tornou um aliado crucial na Ásia, a manutenção das bases em território japonês tem relevância para a estratégia militar norte-americana. ${ }^{24}$ Okinawa é a prefeitura mais distante de Tóquio e, ao mesmo tempo, a mais próxima de cidades como Xangai, Hong Kong, e Manila. Assim, além de receber proteção, o Japão preserva seu centro financeiro, político e cultural dos problemas causados pelo funcionamento das bases militares, e os Estados Unidos, seus interesses de posicionamento global.

Okinawa já foi o centro do reino de Ryūkyū, ${ }^{25}$ independente política e comercialmente até o começo do século 17. Na época, a China exercia forte influência econômica e cultural, cobrando tributos do arquipélago. Em 1609, a situação se alterou, com a invasão do clã Shimizu de Satsuma, autorizada pelo xogunato Tokugawa. O reino passou a pagar impostos também aos colonizadores japoneses. Na Era Meiji (1867-1902), quando o imperador japonês assumiu o comando político-administrativo e iniciou um processo de modernização e expansão imperialista para tornar o Japão a principal potência na Ásia, os interesses em assimilar Okinawa se intensificaram. Em 1879, o império japonês anexou oficialmente a região a seu território, assegurando domínio na região assim como ocorreu quando Taiwan, em 1895, e Coreia, em 1910, tornaram-se formalmente colônias do Japão.

\footnotetext{
${ }^{24}$ Com a vitória de Donald Trump na eleição presidencial norte-americana, em novembro de 2016, agravaram-se as incertezas em relação à situação das bases militares americanas em Okinawa. Durante a campanha, Trump ameaçou fechar todas as instalações caso o Japão não passasse a arcar com a totalidade dos custos de operação. Enquanto moradores e políticos locais expressaram esperanças de conseguirem mudanças efetivas e benéficas a Okinawa, outros acreditam que se trata apenas de uma barganha para repassar ao governo japonês uma parcela maior da conta. $\mathrm{Na}$ ocasião da posse de Trump, em 20 de janeiro de 2017, o primeiro ministro japonês, Shinzo Abe, reforçou a importância de fortalecer a aliança militar com americanos, num discurso em que também defendeu a revisão da Constituição japonesa pós-guerra. Embora ele não tenha mencionado artigos constitucionais específicos, discutem-se as intenções do governo Abe de reivindicar o direito do Japão de declarar guerras contra outras nações, revogado desde a rendição em 1945 (Fifield, 2016; Yoshida, 2017).

${ }^{25}$ O nome das Ilhas Ryūkyū, arquipélago cuja maior ilha é Okinawa, é herança desse passado. Outra denominação para as Ilhas Ryūkyū indica apenas sua localização a sudoeste do território japonês: 南西諸島 (Nansei-shotō).
} 
Iniciado em 1880, o ensino de língua japonesa na prefeitura de Okinawa foi reforçado com o Decreto Imperial sobre Educação, de 1890. Nos extremos do país, ao norte e ao sul, onde as medidas para promover o uso da língua nacional foram adotadas mais severamente, os alunos eram proibidos de falar as diversas línguas locais. Após a vitória do Japão na Guerra Sino-Japonesa, em 1895, ficou evidente que, apesar da histórica relação com a China, Okinawa seria cada vez mais controlada pelo governo japonês. (Bhowmik, 2008; Pajon, 2010; Zohar, 2012).

Localizada ao sul de Okinawa, a capital Naha, onde a artista japonesa Yamashiro Chikako cresceu, foi praticamente toda reconstruída após a Segunda Guerra.
\end{abstract}

Aliás, seu clima subtropical úmido coincide com o de uma cidade-irmã: São Paulo. Amizade selada por mais um acordo político, de papel.

A capital japonesa do turismo tropical e a capital brasileira do trabalho solidárias uma à outra na Lei $\mathrm{n}^{\circ}$ 14.471, de 10 de julho de 2007, da Prefeitura de São Paulo.

No mês de outubro, acontece um festival de três dias nas ruas de Naha, com danças e performances tradicionais. A programação de 2015 incluiu um show com dois personagens da Disney adorados no Japão: Mickey e Minnie. 
Uma corda gigantesca, feita de palha, é a principal atração da festa. Milhares de pessoas participam do cabo de guerra, simulando um ritual celebrado em épocas passadas.

O que moradores, militares norte-americanos e turistas do mundo todo encenam na grande avenida de Naha? No meio da multidão e da brincadeira, puxando, suando, sem ver direito a extensão da corda, alguém se importa com qual lado está ganhando?

Guerras foram travadas em torno das línguas nativas, da cultura e das artes de Okinawa. Hoje, o que resta?

Um mar aberto. Alguns pedaços de corda.

Oki. Nawa.

沖縄 


\section{'Uma praia bonita' - parte 3}

"O turismo de Okinawa nasceu das ruínas da guerra", afirma o historiador Gerald Figal no livro Beachheads: War, Peace, and Tourism in Postwar Okinawa. Na região sul da ilha principal, a mais devastada durante os confrontos, concentrase a maior parte da infraestrutura turística, fundada nos anos 1950 em torno de visitações a locais de batalhas, memoriais, sepulturas coletivas, ossários e cavernas usadas por militares e moradores. Os primeiros interessados eram funcionários norte-americanos das forças de ocupação, veteranos japoneses e famílias que perderam parentes na Batalha de Okinawa (Figal, 2012).

Beacheads é uma expressão criada na Segunda Guerra Mundial: significa uma praia conquistada e defendida para servir de apoio a futuros ataques no território inimigo. Como o livro discute, as praias remetem ao cruzamento dos tropos "palco de batalha sangrenta" e "paraíso tropical", costurados à história de Okinawa no pós-guerra com conotações diferentes dependendo do momento e do ponto de vista.

Devido à desproporção de poderio militar, por mais que houvesse forte resistência, era uma questão de tempo a vitória norte-americana no último confronto travado em solo contra forças japonesas, iniciado em $1^{\circ}$ de abril de 1945 e conhecido como Batalha de Okinawa. Após 82 dias de campanha, os Estados Unidos conquistaram um território importante para lançar novos ataques aéreos contra as principais cidades japonesas.

Estima-se mais de 200 mil mortos nessa batalha histórica. A maioria das vítimas era de moradores de Okinawa, que perdeu mais de um quarto de sua população civil. As consequências físicas e emocionais dessa devastação na ilha desafiam até hoje o significado de "pós-guerra".

No mercado turístico atual, desenvolvido sobretudo a partir da década de 1960, o termo "Ryūkyū" aparece no sentido de "a Okinawa tradicional", um 
atrativo cultural vendido em pacote com as praias. No período anterior à guerra, referências ao antigo reino Ryūkyū tinham uma nuance negativa, discriminatória, caracterizando algo como "pouco japonês" ou não civilizado. A imagem de Okinawa estava associada no restante do Japão a um local atrasado, pré-moderno e sem recursos naturais. (Figal, 2012).

Em debates sobre identidades, raça e preconceitos no Japão contemporâneo, ainda hoje é lembrado o antigo "caso do Pavilhão Antropológico" (Jinruikan jiken $)^{26}$. A polêmica aconteceu na Quinta Exposição Nacional para Promoção da Indústria, realizada em 1903, no Parque Tennōji, em Osaka. Organizado com base no discurso científico da Antropologia moderna, a partir da perspectiva colonialista europeia, o evento gerou protestos sobretudo na China, na Coreia e em Okinawa, ao propor uma exposição com pessoas usando vestimentas étnicas, diante das habitações típicas de seus povoados, construídas apenas para o evento.

Localizado na ala de entretenimento, ao lado de um zoológico, o Pavilhão Antropológico ${ }^{27}$ chegou a exibir membros do povo Ainu (nativo de Hokkaido, ilha no norte do Japão), aborígenes de Taiwan, indianos, javaneses, um turco e um africano. Duas prostitutas trazidas de Okinawa foram apresentadas ao público como "mulheres da corte de Ryūkyū", mas retiradas da exposição após protestos contra a separação étnica. (Bhowmik, 2008; Hur, 2012; Cho, 2014).

De acordo com Hyungju Hur (2012), em sua tese de doutorado sobre as relações da China com as exposições mundiais da virada do século 20, a lógica da exposição de Osaka sustentava a ideia do Japão como modelo de sociedade civilizada a ser seguido pelos países vizinhos. Na tese de doutorado sobre práticas

\footnotetext{
26 人類館事件

27 No folheto em inglês da época, o Pavilhão Antropológico (ou, simplesmente, prédio da Antropologia, na tradução literal do nome dado em japonês) foi apresentado como "the building of the world natives".
} 
culturais de Okinawa em Osaka, Sumi Cho (2014) ressalta que, ao apresentar o progresso do Japão como nação moderna, o evento também tinha o objetivo de demonstrar a capacidade do país de liderar uma missão colonizadora. "In the Osaka Exposition, the implication of Japanese colonialism was clear, in that most of individuals who were displayed were newly colonized (Ainu and Okinawans) or yet to be colonized (Koreans, Taiwanese aborigines, and Javanese)", afirma Cho (2014, p. 38). ${ }^{28}$

Cho critica ainda os argumentos da elite de Okinawa para reagir ao incidente do Pavilhão Antropológico. Conforme expresso em um jornal local, o Ryūkyū Shimpō, e numa carta de protesto, eles ficaram particularmente insultados pelo fato de serem prostitutas as mulheres apresentadas na exposição como pessoas de alto status social. Segundo Cho, nesses manifestos a elite local também lamentou a decisão dos organizadores de escolher nativos de Okinawa para figurarem ao lado de raças "inferiores" como os Ainu e os aborígenes taiwaneses. Como o antigo reino de Ryūkyū fora anexado pelo Japão como uma prefeitura, diz Cho (2015, p. 38), a solução lógica da elite de Okinawa na ocasião foi reivindicar uma "japanização" mais completa, o que impediu uma reflexão mais contundente sobre seu lugar na estrutura de discriminação.

Segundo Gerald Figal, no livro Beachheads, hoje em dia o material promocional das agências de turismo de Okinawa costuma dar ênfase às maravilhas tropicais e do passado do reino de Ryūkyū. Os memoriais de guerra ficaram em segundo plano. Geralmente, os panfletos mostram apenas imagens da Batalha de Okinawa já conhecidas pelos turistas vindos do território central japonês.

\footnotetext{
${ }^{28}$ Tradução livre minha. "Na exposição em Osaka, a implicação do colonialismo japonês era clara, tanto que a maioria dos indivíduos expostos eram recentemente colonizados (do povo Ainu e de Okinawa) ou estavam para ser colonizados (coreanos, aborígenes taiwaneses e javaneses).”
} 
Mesmo assim, o historiador aposta no potencial de iniciativas locais de narrar a memória da guerra, para confundir mais do que confirmar essas imagens. Para ele, é nos locais de visitação, nas apresentações sobre temas ligados à guerra, que a história, "enlatada" para consumo fácil dos turistas, pode começar a vazar.

Um dos pontos mais incômodos e controversos na disputa sobre a escrita da história é a responsabilidade do governo japonês pelo alto número de civis mortos na Guerra de Okinawa, estimado em 140 mil pessoas. Levados a participar de grupamentos de autodefesa, muitos foram atingidos pelos confrontos ou acusados de traição pelo exército imperial japonês e executados. Sobreviventes relatam ainda que, sob coação de soldados japoneses, centenas de pessoas morreram em suicídios coletivos, usando granadas de mão, ferramentas improvisadas, enforcamentos, entre outros recursos desesperados, antes mesmo do começo da batalha.

No artigo "The Politics of Trauma: Compulsory Suicides During the Battle of Okinawa and Postwar Retrospectives”, o historiador Steve Rabson (2010) apresenta um panorama da complexidade de questões envolvidas nessa barbárie. A perspectiva nacionalista da direita se apóia no fato de não existirem documentos oficiais comprovando diretamente a coerção exercida contra civis e no argumento de que os suicídios teriam sido uma demonstração da vontade do povo de se sacrificar em nome do imperador.

De fato, conforme a política imperial difundida na época, os esforços de guerra exigiam dedicação e sacrifício de todos os cidadãos japoneses. Era preferível morrer à vergonha e humilhação de acabar sendo capturado pelo inimigo. Outra ideia bastante divulgada, inclusive pelos oficiais japoneses, era a de que os soldados americanos torturavam cruelmente e matavam seus prisioneiros de guerra. Segundo Rabson, os moradores de Okinawa sofriam 
pressões ainda mais violentas para comprovar a sua lealdade ao imperador, por serem súditos de uma província anexada tardiamente. Além disso, diz ele, a crença na inferioridade racial e cultural do povo local era mais difundida entre os militares japoneses. $^{29}$ Nesse contexto, isoladas num arquipélago no Oceano Pacífico, sem acesso a rotas de fuga, centenas de pessoas se sentiram acuadas e sem alternativas ao sacrifício.

Um dado histórico é usado para ajudar a legitimar os testemunhos dos sobreviventes que viram parentes e amigos serem coagidos a cometer suicídio: nas ilhas de Okinawa sem unidades do exército imperial, os moradores se renderam pacificamente ao exército norte-americano, após responder aos chamados de soldados nipo-americanos atuando como tradutores.

O relato de um sobrevivente da guerra aparece numa instalação com vídeo montada em 2009 por Yamashiro Chikako, com o título "Sua voz saiu pela minha garganta". ${ }^{30}$ Trata-se de um filme de sete minutos, exibido em looping, em que ela explora acontecimentos da Guerra do Pacífico. Num artigo sobre essa obra, Joshua Chambers-Letson (2014) afirma que nela Yamashiro usou seu corpo como condutor para receber as memórias de uma geração mais velha, encenando o elo entre sobreviventes e herdeiros desse legado.

29 Em um artigo incluído na coletânea Imag(in)ing the War in Japan: Representing and Responding to Trauma in Postwar Literature and Film, a respeito da obra do escritor Medoruma Shun, Davinder L. Bhowmik comenta textos ficcionais e ensaios em que o autor deixa explícitos casos de extrema violência ocorridos entre moradores de Okinawa durante a guerra: "Embora esse tipo de crueldade seja menos conhecido que o péssimo tratamento dado aos moradores de Okinawa pelos soldados japoneses, não se tratam de casos desconexos, já que muitos dos que atacaram seus próprios vizinhos podem ter feito isso para demonstrar lealdade ao Estado. Medoruma expressa através de Gozei [personagem de um de seus contos] seu reconhecimento de crueldades como essa e descreve em seus ensaios as experiências negativas de sua mãe, a quem moradores de Okinawa negaram abrigo durante a batalha" (Bhowmik, p. 222, tradução livre minha).

${ }^{30}$ Tradução livre minha. O título desse trabalho foi traduzido em inglês como "Your Voice Came Out Through My Throat". No original em japonês é "anata no koe wa watashi no nodo wo tōtta”[あなたの声は私の喉を通つた]. 
O vídeo mostra o rosto da artista num fundo branco. Vestindo uma blusa também branca, ela olha para o lado, evitando olhar diretamente para a câmera. Conforme detalha Chambers-Letson, Yamashiro abre a boca e escuta-se a voz de um homem idoso. Os lábios estão sincronizados com o relato dele, a história de como sobreviveu à guerra. "De um abrigo antibombas para outro, sem comida, sem água. Fomos forçados a viver desse jeito. Nem sequer dava para trabalhar nos campos por comida”. Nesse começo, a sincronia é perfeita e lágrimas começam a se formar lentamente nos olhos da artista. A voz se interrompe e há uma longa pausa. "Então nos reunimos num extremo da ilha e aí as pessoas se jogaram dos penhascos no mar”. Nesse ponto, Yamashiro quebra o ritmo, fecha os lábios. O homem continua: "Então as pessoas se jogaram dos penhascos no mar e se mataram”. Ele para de falar e dá para ouvir soluços e um coro de outras vozes de idosos se juntando em volta dele e o confortando (o trabalho surgiu a partir de entrevistas realizadas por Yamashiro em um asilo em Okinawa). "Todas as pessoas da minha família se jogaram do penhasco e morreram.” Há mais uma longa pausa, com a artista olhando para frente, ainda de acordo com a descrição de Chambers-Letson.

Na parte final do vídeo, Yamashiro volta a abrir a boca para dar espaço à voz do homem: "Eu vi muitas pessoas morrerem... Todos os corpos foram enterrados sem terem sido identificados. Depois do fim da guerra, nós cavamos de novo para recuperar os ossos... Mas não conseguíamos saber a quem cada osso pertencia. A maioria de nós não pegou os ossos novamente [os lábios da artista ficam dessincronizados com a voz]. Não dava.” Nesse momento, uma projeção do rosto do idoso é sobreposta à imagem de Yamashiro. Quando ele expressa suas esperanças, ela começa a falar pela primeira vez e as vozes se tornam uníssonas: "Então não podemos deixar que a guerra aconteça novamente. Devemos ser contra a guerra, não importa o motivo. Ela desperdiça o esforço das pessoas, destrói a vida delas".

Um ponto relevante nesse trabalho é que, entre os entrevistados no asilo de Okinawa, Yamashiro escolheu uma pessoa que sobreviveu à batalha na ilha de 
Saipan, ${ }^{31}$ de modo a enfatizar, na opinião de Chambers-Letson, a experiência colonial compartilhada por sobreviventes de batalhas travadas nos territórios ocupados pelas forças militares japonesas - o próprio idoso, em um dado momento de seu relato, afirma: "Acho que a Batalha de Okinawa foi igual".

No Japão pós-guerra, a suposta falta de documentação "científica" a respeito da morte de civis na Batalha de Okinawa é usada como justificativa para censurar menções aos suicídios coletivos forçados. Desde a década de 1950, os livros adotados nas escolas aparecem no centro dessa disputa.

Mais recentemente, em 2007, o Ministério da Educação aprovou revisões no texto de livros didáticos de História, de modo a enfraquecer a relação entre os suicídios em massa e as ações do exército imperial. De acordo com o parecer emitido pelo conselho responsável pela inspeção de livros didáticos, as alterações seriam necessárias pela dificuldade de se comprovar que os suicídios ocorreram após ordens dadas pelos militares. A Assembleia da Prefeitura de Okinawa aprovou por unanimidade uma resolução pedindo a anulação dessas revisões, mas recebeu resposta negativa por parte do ministério, alegando se tratar de uma decisão cabível apenas ao conselho. (Rabson, 2010; Nozaki, Selden, 2009; Massaki, 2008).

No artigo, "Japanese Textbook Controversies, Nationalism, and Historical Memory: Intra- and Inter-national Conflicts", Yoshiko Nozaki e Mark Selden (2009) discutem como os livros didáticos afetam a construção da memória nacional japonesa e produzem silenciamento em relação à política colonialista e militar do antigo império japonês. Segundo os autores, durante a guerra o ensino de História era pouco ligado à pesquisa historiográfica e os livros didáticos

\footnotetext{
${ }^{31}$ Principal ilha do arquipélago das Marianas, Saipan foi colonizada pelo império japonês do fim da Primeira Guerra Mundial até a perda do controle do território para as forças norte-americanas em julho de 1945 .
} 
estavam entre os veículos mais importantes para disseminar narrativas históricas centradas na perspectiva do governo imperial. O sistema de avaliação e revisão dos livros didáticos teria contribuído para a manutenção de estruturas desse sistema educacional no período pós-guerra. Pelo esquema atual, o governo publica diretrizes e as editoras interessadas desenvolvem os textos didáticos, que precisam ser aprovados antes de serem adotados nas escolas públicas e até mesmo privadas. Cada instituição de ensino tem a liberdade de escolher entre os livros aprovados pelo conselho do Ministério da Educação. Ainda de acordo com Nozaki e Selden, é comum existirem pedidos de revisão dos rascunhos submetidos pelas editoras, especialmente quando se trata de assuntos mais controversos como a Guerra do Pacífico.

Os autores abordam um caso ocorrido no processo de 1981-82, quando várias revisões foram solicitadas para a seguinte passagem, escrita por Eguchi Keiichi: "Na batalha [de Okinawa]... aproximadamente 100 mil combatentes e 200 mil civis foram mortos. Além disso, aproximadamente 800 moradores de Okinawa foram assassinados pelas forças japonesas por motivos como dificultar o combate." Eguchi tentou submeter versões alteradas desse trecho, mas acabou precisando eliminar o tópico de seu texto final. Uma de suas principais fontes, o livro História da Prefeitura de Okinawa, compilado pelo governo local de Okinawa, foi desacreditada por se tratar de uma coleção de narrativas pessoais (Nozaki; Selden, 2009, p. 6).

Em 2007, o posicionamento do Ministério da Educação em relação à historiografia sobre os suicídios na Batalha de Okinawa foi o de permitir que os autores dos textos didáticos se referissem ao "envolvimento" das forças japonesas, mas não à coerção ou termos correlatos. $\mathrm{O}$ parecer do governo gerou fortes protestos na província e a maior manifestação desde 1972, quando Okinawa voltou a ser governada pelo Japão. (Nozaki; Selden, 2009). 
De certa forma, os livros didáticos são parte do que deixamos de modo planejado e estruturado como herança para as gerações seguintes. Narrativas compiladas, editadas, mastigadas para fins de aprendizado, de acúmulo de conhecimento. No entanto, existem muito mais tipos de tecidos narrativos e naturezas distintas de coisas atravessando os projetos pedagógicos — resíduos que muitas vezes nem conseguimos nomear.
\end{abstract}




\section{Escuta na pele, escuta em sinestesia}

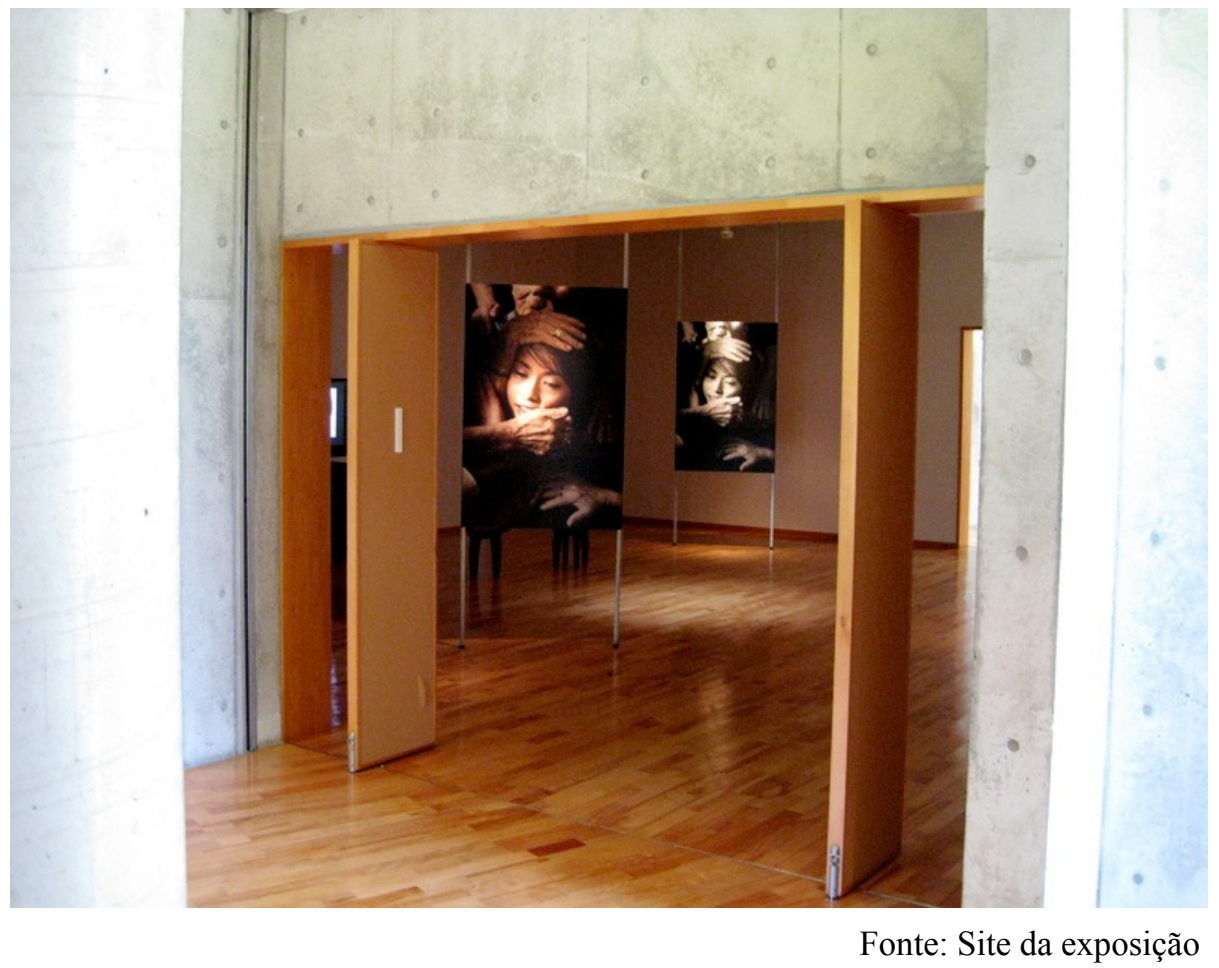

Imprimir em imagens a experiência de ouvir feridas caladas, porém ainda ressonantes. Feridas não tratadas de uma geração que viveu a Guerra do Pacífico na Ásia e, hoje, transmite seus últimos testemunhos. Somos seus herdeiros inevitáveis, embora extremamente distantes, no tempo e na vida, incapazes de perceber e compreender os fragmentos de um legado que será deixado — para trás?

As duas fotografias acima, uma colorida e outra em preto e branco, foram tiradas em 2008 e exibidas pela artista Yamashiro Chikako na instalação Herança Virtual, no Museu de Arte Sakima. Elas fizeram parte da exposição "Into the Atomic Sunshine - Post-War Art under Japanese Peace Constitution Article 9", realizada entre abril e maio de 2009, com cooperação da Galeria Rougheryet. Além de Sakima, localizado na cidade de Ginowan, a poucos metros da base área 
norte-americana de Futenma, a mostra também ocupou duas galerias do museu da Prefeitura de Okinawa, em Naha.

De acordo com Laura Hein e Rebecca Jennison (2011), Yamashiro começou a se interessar pelo tema das narrativas e memórias de guerra após junho de 2007, quando o governo japonês alterou passagens em textos didáticos de História, de modo a negar que o exército imperial tenha forçado civis a cometerem suicídio na Batalha de Okinawa.

A artista decidiu entrevistar idosos em asilos de Okinawa e também participou de sessões de terapia em grupo em que eles falavam sobre eventos do passado. Yamashiro comentou esse trabalho em entrevista à artista Soni Kum, incluída no DVD que acompanha o livro Still Hear the Wound:32

Eles conversavam por cerca de duas horas, mais ou menos, criando um espaço no qual podiam escutar suas histórias de Okinawa antes e depois da guerra. Em seguida, fizemos uma sessão de fotos, uma espécie de workshop, e foi aí que eu tirei a foto. Havia alguns imigrantes entre eles, nascido em lugares como Saipan. Não tinham vivido a Batalha de Okinawa, mas eram capazes de falar sobre suas experiências de guerra em Saipan. Um pouco depois, enquanto eu estava tirando fotos, conversei com eles. Tinha sentido que não tinham conseguido expressar muitas coisas através das palavras. Então, pedi para colocarem as mãos em mim e falei que eles poderiam transmitir pelo toque essas coisas que precisavam expressar. Foi nesse momento que tirei a foto. Quando estávamos falando sobre a guerra, os idosos pareciam ter vários momentos em que as palavras lhe faltavam. Imaginei que provavelmente isso acontecia quando estavam lembrando de um evento trágico. Era nesses momentos, eu acho. Quando tentavam falar sobre seus

\footnotetext{
32 Yamashiro Chikako, em entrevista gravada por Soni Kum, Still Hear the Wound: Toward an Asia, Politics, and Art to Come, DVD, The Cornell East Asia Series, 2015. O áudio original em japonês foi traduzido para o inglês por Andrew Harding. Eis a fala de Yamashiro na tradução de Harding, na qual baseei minha tradução livre para o português: "They spoke for about two hours or so, creating a space in which they could listen to each other's stories of pre-war and post-war Okinawa. Afterwards we had a photography session, kind of like a workshop, and that's where I took the photo. There were a few migrants amongst them, who had been born in places like Saipan, who hadn't experienced the Battle of Okinawa but were able to talk about their experiences of the war in Saipan, and while I was taking photos later on I told them that while they had been speaking I'd felt that there were a lot of things that they hadn't been able to express in words, so I asked them to place their hands on me. I told them that they could convey the things that they needed to convey, but hadn't been able to through words, by touching me, and that's when I took the photo. As we spoke about the war, the elderly people seemed to have moments now and again when words failed them, and I imagine that this was probably when they were recalling a tragic event. It was at those times I think. When they tried to speak about their painful moments, they came to a point in which words ceased, and then their hands would start to tremble, and then tears would start to flow. But they didn't stop talking. There was a huge gap between their age and my own. They said that they knew I'd not had any experiences of the kind that they'd had and that I probably wouldn't understand them, but that they'd still try and convey it to me in words. The words didn't stop. They kept trying to get it across to me. But there was a point when they simply weren't able to vocalize it, when it seemed that the session was going to end with so much left unsaid, and it was at this point, when I was taking their photo, that I asked them to convey it to me through touch. They all enveloped me, touching me, soothing me as though I was a baby.”
} 
momentos de dor, eles chegavam a um ponto em que as palavras cessavam, as mãos começavam a tremer e então as lágrimas caíam. Mas eles não pararam de falar. Havia uma enorme lacuna entre a idade deles e a minha. Eles disseram que sabiam que eu não tinha tido nenhuma experiência parecida com a deles e que eu provavelmente não os compreenderia, mas ainda assim eles tentariam transmiti-las em palavras para mim. As palavras não pararam. Eles continuaram tentando fazer com que elas chegassem até a mim. Mas havia um ponto em que simplesmente não eram capazes de vocalizá-las. Quando a sessão parecia estar chegando ao fim com tanta coisa ainda não dita, e foi neste ponto, quando eu tirava fotos deles, que pedi a eles que transmitissem suas experiências para mim através do toque. Eles me envolveram, tocando e me acalentando como um bebê. (Yamashiro, DVD, 2015, grifo meu).

A sugestão de Yamashiro para a transmissão pelo toque das sensações mais dolorosas do passado se deu em meio à insistência em tentar alcançar as palavras, conforme seu relato na entrevista acima. As palavras não desapareceram completamente durante o encontro: atravessavam o ambiente, faltavam, eram retomadas, voltavam a ficar escassas, em movimentos ondulares, oscilantes. Além disso, o encontro se tornou possível por meio do contato com a forma arcaica do acalentar e, portanto, em contato com o ritmo das cantigas de ninar. Cabe ressaltar ainda a heterogeneidade de experiências não apenas entre gerações, pois mesmo os idosos integrantes do grupo vinham de backgrounds bastante distintos.

No catálogo online da exposição, o trabalho da artista é descrito por meio desta pergunta: "Mesmo sem jamais terem experimentado a guerra, nossos corpos podem herdar a experiência da Batalha de Okinawa?". ${ }^{33}$ A meu ver, essa pergunta só pôde ser formulada porque algo já tinha acontecido - contida na pergunta já estão presentes resíduos que ninguém teve o poder de desviar ou evitar. São resíduos de herança, ou talvez seja melhor dizer, heranças residuais que caem nos corpos, não necessariamente por relações de parentesco ou de sangue, mas por afinidades afetivas diversas e impossíveis de serem categorizadas. Essas heranças residuais podem surgir na forma de silêncios em queda livre, despencando no ar, transitando os territórios e corpos, até subitamente baterem onde encontram resistência.

Em outras palavras, corpos herdam parcialmente experiências que não viveram diretamente por meio desses resíduos mínimos, formas de afetos não-

\footnotetext{
${ }^{33}$ Tradução livre minha da seguinte frase no catálogo em inglês: "Can our bodies, which have
} never experienced war, inherit the Okinawa war experience?". 
verbais. O pedido de toque feito por Yamashiro, em resposta aos anseios à sua volta durante o encontro com os idosos, só foi possível porque seu corpo já chegou ali marcado (tocado), de algum modo, por uma herança silenciosa. Essa é minha aposta aqui nesta tese: alguma herança residual já havia caído nas mãos da artista.

Essa ideia de uma marca, fenda ou abertura no corpo dando passagem a algo externo, às experiências dos outros, aparece na conversa entre a professora Lee Chonghwa e o músico e compositor Takahashi Yūji publicada no livro Still Hear the Wound (2015, p. lvii-lxix), quando eles discutem as nuances de significado do verbo japonês kikoete $k u r u^{34}$ — o contexto é um debate sobre a noção de som e suas implicações filosóficas, culturais e políticas. Para Takahashi, kikoete kuru (vir a ser ouvido) ${ }^{35}$ transmite a ideia de aceitar ou receber alguma coisa, enquanto kiku (ouvir) significa que algo atingiu seu alvo. No fim das contas, os dois verbos promovem a escuta, mas não é trivial a diferença entre cada processo.

Para Lee, kikoete kuru se aproxima mais de sua própria experiência com o som, pois ele sempre parece vir de algum outro lugar em sua direção. $\mathrm{Na}$ expressão kikoete kuru, diz ela, o som de fato "vem". A relação com o espaço e o tempo é outro ponto interessante ressaltado por Lee na sua percepção do termo:

\begin{abstract}
Naquele momento em que algo é transformado, de estar lá ou muito longe para estar 'aqui', esse é o momento de dizermos 'Ah, isso veio a ser ouvido'. Naquele instante exato em que passado e presente colidem um com outro. (Lee, 2015, p. lviii, tradução livre minha)
\end{abstract}

O "vir a ser ouvido" é um momento de fusão entre o "lá longe" e o "aqui perto", entre o antes e o agora - quando essas categorias se tornam intercambiáveis, acrescenta Takahashi. Nesse instante, os sons são pronunciados, sem estarem fixos em um ponto específico do espaço e do tempo.

Lee acredita ainda que esse ponto no qual alguém começa a "receber" o som não é de passividade, pelo contrário. "[Kikoete kuru] sugere que já há algo sendo

\footnotetext{
${ }^{34}$ Como explica Lee Chonghwa (2015, p. lviii), a expressão japonesa kikoete kuru é formada pela junção do verbo kikoeru (ser ouvido, conseguir ouvir) com verbo kuru (vir).

${ }^{35}$ Brett de Bary e Rebecca Jennison traduziram kikoete kuru para "coming to be heard".
} 
guardado lá dentro, algo contido ali", afirma. "Não estou falando de ouvir palavras, mas de alguma coisa como o ritmo. O que 'vem a ser ouvido' é primeiro um tipo de ritmo" (Lee, 2015, p. lix).

Considero que essas reflexões de Lee e Takahashi sobre as sutilezas do "vir a ser ouvido" ajudam a compreender por um ângulo instigante o trabalho de Yamashiro: um tipo de receptividade já presente nos corpos para onde vão os silêncios, justamente aqueles que acabam por herdar suas ressonâncias, e a possibilidade de criação (a partir da recepção dessas heranças) de um ponto de conexão entre temporalidades e localidades distintas. E, pensando nos silêncios que vêm a ser ouvidos, a conversa de Lee e Takahashi nos deixa ainda uma pista: eles pulsam com ritmo.

Kikoete kuru me remete ainda à experiência na escola japonesa, cujas salas de aula improvisadas não tinham paredes, somente divisórias de madeira. Ali os diferentes níveis de proficiência na língua se cruzavam, os temas, as lições gramaticais. O próprio território deixava vazar, desafiava a sequência linear a ser seguida pelo aluno. Se conseguisse manter a atenção, havia coisas ali para vir a ser ouvidas, sons chegando de tempos e lugares distintos.
\end{abstract}




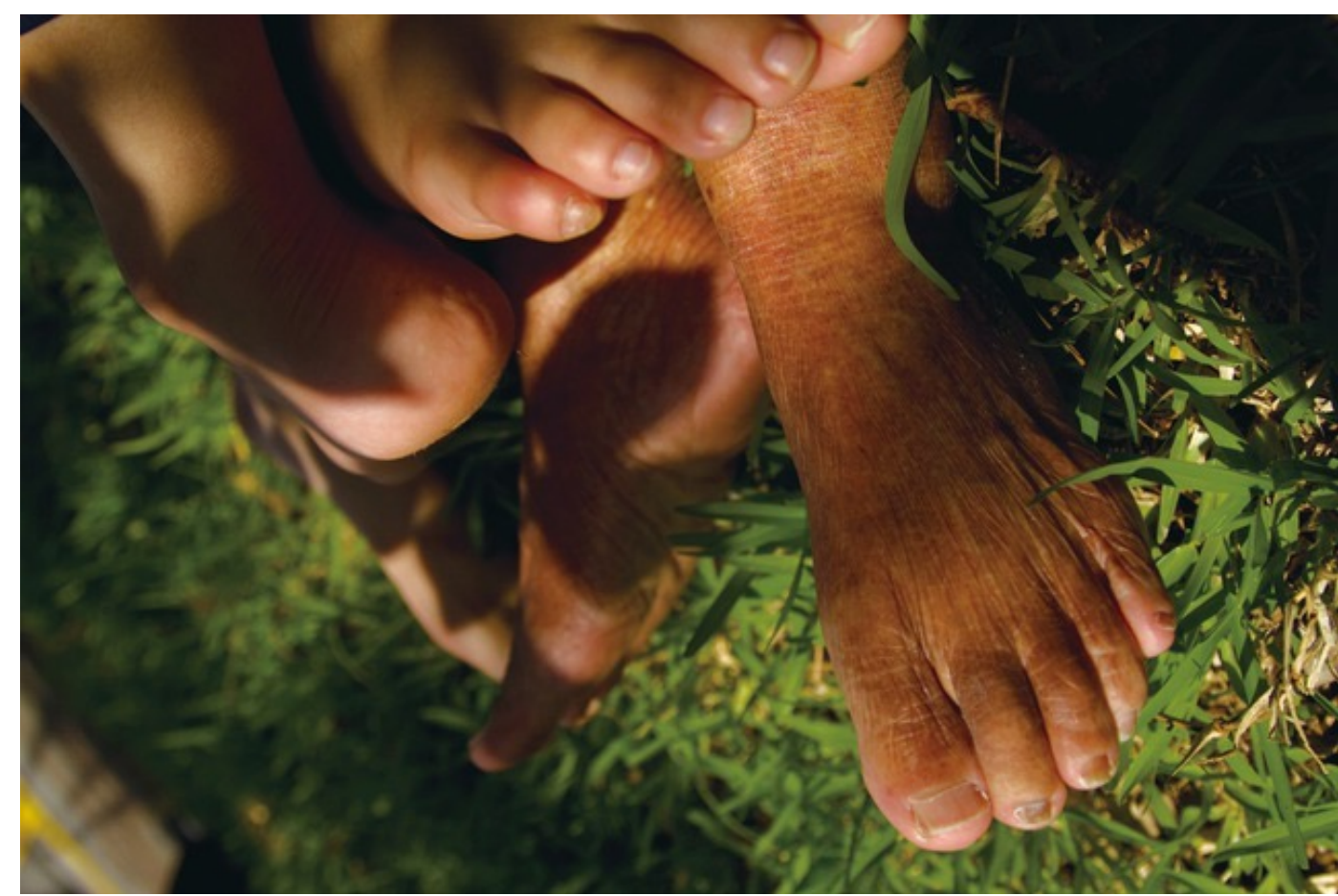

Fonte: Site do Suijo no hito Production ${ }^{36}$

Nas fotografias de Yamashiro de Herança Virtual, como também nas da série Coro de melodias ${ }^{37}$ (2010), na qual a artista fotografou um grupo de amigos, jovens e velhos, numa floresta de Okinawa (foto acima), as texturas da pele das pessoas retratadas surgem em detalhes, especialmente com os contrastes de sombra e luz. Ao mesmo tempo, há um grande vazio, imperceptível somente a partir do estímulo visual. Sem explicitar a dor daquelas pessoas ou das experiências passadas, os procedimentos da artista estimulam sensibilidades em cruzamento, em sinestesia: abrem-se possibilidades para termos uma percepção do tamanho do silêncio de uma geração.

Em uma entrevista publicada no site do museu Guangdong, na China, a artista diz que tentou ouvir as experiências contadas pelos idosos imaginando, tanto quanto possível, que elas poderiam ter sido suas também, evitando tomar suas falas de maneira objetiva, como a dor de outras pessoas. Entretanto, deparou-

\footnotetext{
36 水上の人プロダクション

37 コロスの唄
} 
se com momentos cruciais em que conseguia imaginar até certo ponto, mas não compartilhar inteiramente a vivência de uma pessoa. Segundo Yamashiro, foi muito difícil, como ouvinte, imaginar o que eles estavam deixando de falar em seus relatos, o que exatamente não ousavam mencionar ao falar da experiência de terem testemunhado a morte de parentes e amigos.

Embora o tempo e a memória sejam irrecuperáveis, Yamashiro, velhos, jovens e crianças de Okinawa resistem em tentativas de tocar ou se aproximar das falhas silenciosas da história oficial, sem deixar de assumir que as palavras não podem reverter ou apagar por completo anos e décadas de silêncio.

Assim como o esquecimento (Goés, 2015), ele nunca é totalmente preenchido. Yamashiro cria formas de ouvir silêncios existentes não por decisão consciente dela. Formas de herança, sobram na casa como indesejáveis manchas nas paredes, permanecendo depois que os móveis se vão. Suas fotografias não recuperam o discurso articulado, não explicam racionalmente a história, tampouco o encadeamento de acontecimentos.

Resistem, ainda assim, ao proporem um projeto de escrita coletiva de história fundado na necessidade de construção de uma escuta coletiva. Mais além, trata-se de reconhecer essa necessidade como uma urgência da nossa contemporaneidade. Poderia haver surdez maior do que a decisão deliberada, reiterada, sistemática de não querer ouvir?

A meu ver, um projeto de escuta coletiva de silêncios e murmúrios, a partir de imagens que nos convidam a experiências de sinestesia, oferece caminhos promissores diante da provocação de Rosalind C. Morris (2010) na introdução de Can the subaltern speak? Reflections on the history of an idea, volume crítico sobre o célebre ensaio de Gayatri Spivak: "Embora Pode o subalterno falar? tenha respondido negativamente à sua própria questão, a pergunta que desdobra — como podemos aprender a escutar? - permanece radicalmente aberta". 
Uma célebre pintura poderia ser colocada, à primeira vista, no extremo oposto das feridas murmurantes das fotografias de Yamashiro Chikako. Na tela de O grito (1893), do norueguês Edvard Munch, uma figura sem feições nítidas leva as mãos ao rosto, escancarando a boca num grande "o" oval. Transmite angústia e desespero de costas para a bela paisagem do porto e dos fiordes de Oslo.

O "grito" da imagem, porém, distancia-se da voz humana. Não trata de um homem ou uma mulher, e sim de uma figura deformada, alongada. As mãos compridas na face parecem um esforço de afastar o horror, de abafar o som atormentador.

O mar e o céu de um vermelho intenso são pintados em linhas curvas, distorcidas. Apenas a ponte de madeira retilínea, com sua grade de proteção, separam a figura do infinito da natureza e seu silêncio absurdo.

Num manuscrito traduzido do norueguês para o inglês e publicada pelo Museu Munch, o pintor faz anotações sobre a experiência que teria inspirado sua obra-prima:

Eu estava andando por uma rua numa tarde - a cidade de um lado e o fiorde abaixo de mim. Estava cansado e doente - fiquei em pé contemplando o fiorde. O sol estava se pondo - as nuvens se tornaram vermelhas - como sangue. Senti como se um grito tivesse passado pela natureza - pensei ter ouvido um grito. Pintei essa imagem - pintei as nuvens como sangue de verdade. As cores gritaram. Isso se tornou a pintura do grito na frisa da vida. (Munch, 1928-1929, grifos meus). ${ }^{38}$

O grito cor-de-sangue atravessando a pintura de Munch está fundido naquela camada do silêncio que pode vir a falar. Não a fala dos humanos, evidentemente, pois silere ${ }^{39}$ acontece na exclusão da palavra e na ausência da voz. É bem mais contundente: apenas grita (sem som) no frio entardecer.

\footnotetext{
${ }^{38}$ Tradução livre minha. Segue a transcrição em inglês: "I was walking down a road one evening — on one side the city and the fjord lay beneath me. I was tired and ill - I stood gazing out over the fjord. The Sun was setting - the clouds turned the colour red - like blood. I felt as though a scream passed through nature - I thought I heard a scream. I painted this image - painted the clouds like real blood. The colours screamed. It became the picture scream in the frieze of life."
}

${ }^{39}$ Cf. nesta tese as p. 22-27, do ensaio "Perto do silêncio". 
Um silencioso grito caiu nas mãos de Munch naquele dia - acredito. E, nesse sentido, as duas imagens, $O$ grito e Herança Virtual, operam a partir de materiais sobrepostos.

Muito tempo depois de ter conhecido a série de fotografias Herança Virtual, de Yamashiro Chikako, reparei em semelhanças com a capa do disco Abraçaço, na qual o rosto de Caetano Veloso é envolvido por mãos e braços.

Nessa imagem os gestos aparentam ter marcações bem definidas, como nas coreografias: dois pares de mãos vêm detrás, abraçando testa e ombros do cantor. Outros dois pares de mãos vêm pela frente, acariciando bochechas, queixo e pescoço.

De todo modo, o disco foi lançado em 2012, quando o consagrado músico baiano completava 70 anos. O "abraçaço" é dado pelos músicos da banda Cê, formada por jovens, com quem Caetano lançou uma trilogia de álbuns.

Consideradas as distâncias entre os dois trabalhos, além do contexto de que, no caso de Abraçaço, trata-se de uma imagem de divulgação do disco, pensei ser proveitoso imaginar cruzamentos, pois também Caetano está colocando em pauta o contato entre diferentes gerações, de músicos, de gêneros musicais.

Em reportagem publicada pelo jornal O Globo (Lichote, 2012), Caetano diz que a palavra "abraçaço" tem uma reverberação e parece um eco mesmo quando escrito, pela repetição da cedilha. "É como se fossem círculos concêntricos de abraços, que vão se expandindo", afirma. E se essa maneira de compreender o "abraçaço" também se referisse àquele dado pelos velhos de Okinawa em Yamashiro? 


\section{Sons arcaicos}

Afinal, como podemos aprender a escutar? Anestesiados, amortecidos, podemos falar, podemos até discursar sobre a dor dos outros. Nada nos impedirá.

Só ouvir a dor do outro corta realmente em algum lugar da carne.

Então precisamos dos portões para fechar os ouvidos, mesmo ao custo de mantermos algo tão difícil de movimentar. Portões pesados de madeira maciça, cujas dobradiças enferrujam, endurecem com o tempo.

Sozinho, no meio de uma ilha, mato adentro, o barulho é ensurdecedor, vem de todos lados. Não sabemos suportar.

Estamos tentando falar mais alto uns com os outros, tão roucos, tão cansados, exauridos... É possível continuar sem construir projetos coletivos de escuta?

Escuta coletiva, escuta da sobrevivência.

$\mathrm{Na}$ fazenda do Buriti Bom, as pessoas escutavam o corpo da noite e os seres que o formam: "Era uma necessidade. O sertão é de noite" (Rosa, 2013).

O mais velho de todos está à beira da loucura, sequer consegue dormir. "Chefe Ezequiel, o homem que chamava os segredos todos da noite para dentro de seus ouvidos", escreveu Guimarães Rosa.

"Lua feita, o silêncio se afunda, afunda — o silêncio se mexe, se faz" — a frase pode ter sido anotada no caderno de capa de couro. Rosa anotava nele os acontecimentos, recolhia histórias, inventava tudo.

O silêncio se mexe, se $f a z$. 
O enredo da novela é interrompido pela descrição exata de uma matéria que pode grudar no corpo de qualquer um de nós: "O silêncio entorna os barulhinhos todos num, que na gente amortece os ouvidos; e passa por cima, por cima engrossa um silêncio outro, que é a massa de uma coisa."

As casas envelhecidas deixam mais expostas as massas de silêncio e esquecimento. Nos rodapés, nos cantos das paredes, principalmente. As camadas de tinta e verniz modernizam de fora para dentro, mas resquícios sobrevivem suturas, cortes, manchas estufadas, imperfeições na matéria.

Um projeto para construir coletivamente modos de escuta pode começar pelo reconhecimento de certos resíduos deixados pela modernidade, formas arcaicas de ser e existir silenciadas e descartadas por muitos anos.

Não se trata de enaltecer o passado ou montar altares para suas linhagens, suas hierarquias. O trabalho de peneirar silêncios herdados é de um cuidado extremo, delicado. Passa por indagações como essa: o que conversa com nossos dilemas atuais? A que temas, a que questões acabamos retornando, em círculos, em espirais?

O que é preciso reconhecer de uma vez por todas?

Foi no meio de uma noite, indo para a madrugada, diz Rosa — não sei se antes ou depois da festa de Manuelzão, isso não importa realmente.

"Mas cada um sentiu, de repente, no coração, o estalo do silenciozinho que ele fez, a pontuda falta da toada, do barulhinho" (Rosa, 2001). 
Manuelzão se levanta, sai da casa com uma tocha na mão, à frente das crianças e dos cachorros latindo.

O chio se despede, eles estranham.

“Triste duma certeza: cada vez mais fundo, mais longe nos silêncios, ele tinha ido s'embora, o riachinho de todos. Chegado na beirada, Manuelzão entrou, ainda molhou os pés, no fresco do lameal.”

Pisar no silêncio de um riozinho à beira de desaparecer.

“O riacho soluço se estancara, sem resto, e talvez para sempre. Secara-se a lagrimal, sua boquinha serrana. Era como se um menino sozinho tivesse morrido."

Outro dia, choveu tanto que inundou a sala e o corredor do quintal. Aqui em casa chove forte. A água sempre escorre por aqui. Deve haver um fundo, um fundo do fundo, que atrai com todas as forças a chuva e enlameia o que deveria ser a passagem do carro. Penso, às vezes, se ainda há alguma coisa da pitangueira por debaixo desse cimento que mandaram colocar.
\end{abstract}




\title{
Pó rosa
}

Na casa que existiu numa época outra, havia tempo para se olhar cada canto. Da cama observava a poeira suspensa no ar, visível somente na luz do fim da tarde. O lençol e o colchão, movimentando-se conforme o jogo de peso do corpo, lançavam ar para cima, para os lados, dando o ritmo à nuvem de pó.

Aquela exata inclinação dos raios de sol era fundamental para manter tudo girando em compasso.

\begin{abstract}
A casa não era sua, nunca foi - porém, não deixa de fazer parte das suas heranças, ainda que silenciosas. São heranças materiais, sim, mas de natureza invisível em cartórios e documentos afins.

Em nenhuma outra casa haverá tanto tempo... livre.
\end{abstract}

A atenção pode estar plena para participar da dança de todas as tardes, em frente à janela.

Mais de 30 anos se passaram. De outro modo, comprimido, diferente da leveza das partículas de ar flutuando no raio de sol das cinco horas. 
Ele chegou há poucos dias. Pequeno, vindo de outro clima, outro território. Sabia muito bem que não temos parentesco nem falamos a mesma língua.

Quis viver intensamente o tempo disponível para aproveitar aquela casa que não deixa de fazer parte das suas heranças. O ritmo da criança é só dela, só ela consegue aquele extremo tão preciso. Pulando, correndo, lutando. Também gostou de procurar esconderijos e dar sustos nas pessoas.

Numa tarde, ele estava brincando na cama, agitado e risonho, cada vez mais.

De repente, parou tudo. Surpreendeu-se.

Começou a apontar para algo atrás de mim, sem dizer nada. Não sabia o nome da coisa nem explicar o que era. Insistia nos gestos, estava absolutamente encantado. Era urgente e necessário que eu olhasse, não poderia mais continuar de outro modo.

Ele mostrou o raio de pôr de sol atrás de mim, cortando o ar em direção à cama. Entre uma coisa e outra: as partículas de poeira quase cor de rosa, algumas quase douradas, flutuando com os movimentos do travesseiro, das camadas de lençóis. 
Mesmo tão agitado, ele conseguiu escutar aquela dança silenciosa. A vista da poeira diante da janela da casa de seus avós. Um território estrangeiro para ele (assim como era para mim a casa dos meus avós), pertencente a outra língua e a outro tempo.

O que ele, tão novo, poderá entender das experiências daqueles que viveram e morreram naquela casa? O que jamais poderá entender daquilo que o atinge e resta de herança nas suas mãos, mesmo sem nunca ter sido rastreado ou sequer nomeado?

Muitas experiências do passado são intraduzíveis racionalmente para uma criança. Mas, se tiverem o tempo suficiente, elas notam até mesmo a poeira dançando no ar.

E isso basta por hoje. 


\section{Referências bibliográficas}

AIBE, Mayumi Senra. Said e Barthes: Orientes possíveis nas escritas de si. Rio de Janeiro, 2013. 75p. Dissertação (Mestrado em Literatura, Cultura e Contemporaneidade) - Departamento de Letras, Pontifícia Universidade Católica do Rio de Janeiro.

BARTHES, Roland. A preparação do romance I: da vida à obra. Tradução de Leyla Perrone-Moisés. São Paulo: Martins Fontes, 2005.

BARTHES, Roland. O império dos signos. Tradução de Leyla Perrone-Moisés. São Paulo: Martins Fontes, 2007.

BARTHES, Roland. O neutro: anotações de aulas e seminários no Collège de France, 1977-1978. Tradução de Ivone Castilho Benedetti. São Paulo: Martins Fontes, 2003.

BHOWMIK, Davinder L. Fractious Memories in Medoruma Shun's Tales of War. In: STAHL, David; WILLIAMS, Mark (Orgs.). Imag(in)ing the War in Japan: Representing and Responding to Trauma in Postwar Literature and Film. Leiden; Boston: Brill, 2010, p. 203-228.

BHOWMIK, Davinder L. Writing Okinawa: Narrative acts of identity and resistance. Abingdon; Nova York: Routledge, 2008. Versão e-book.

CHAMBERS-LETSON, Joshua. 'A Weak Messianic Power': Yamashiro Chikako's 'Your Voice Came Out Through My Throat'. Trans-Asia Photography Review, Ann Arbor, v. 5, n. 1, 2014. Disponível em: <http://hdl.handle.net/2027/ spo.7977573.0005.105>. Acessado em: 15 jul. 2015.

CHO, Sumi. The Politics of Difference and Authenticity in the Practice of Okinawan Dance and Music in Osaka, Japan. Ann Arbor, 2014. 318p. Tese (Doutorado em Antropologia) - Departamento de Antropologia, University of Michigan.

LEE, Chonghwa (Org.). Still Hear the Wound: Toward an Asia, Politics, and Art to Come. Tradução: Rebecca Jennison e Brett de Bary (Org.). Ithaca, Nova York: The Cornell East Asia Series, 2015a. 
LEE, Chonghwa. Still Hear the Wound. In: 'Still hear the wound': Art, Affect, and Post-Colonial Memory in Japan, Panel One: Poetics of Testimony and the Former 'Comfort Women' Issue, 2015b, Cornell University, Ithaca (EUA). Workshop.

LEE, Chonghwa (Org.). Zanshō no oto: ajia, seiji, aato no mirai e. ${ }^{40}$ Tóquio: Iwanami Shoten, 2009.

LESSER, Jeffrey. A Discontented Diaspora: Japanese Brazilians and the Meanings of Ethnic Militancy, 1960-1980. Durham: Londres: Duke University Press, 2007. Versão e-book.

LICHOTE, Leonardo. 'Abraçaço': a melancolia do medalhão rebelde Caetano Veloso. O Globo, Rio de Janeiro, 30 nov. 2012. Disponível em: <http:// oglobo.globo.com/cultura/abracaco-melancolia-do-medalhao-rebelde-caetanoveloso-6874094. Acesso em: 20 nov. 2016.

FIGAL, Gerald. Beachheads: War, Peace, and Tourism in Postwar Okinawa. Lanham: Rowman \& Littlefield Publishers, 2012. Versão e-book.

FIFIELD, Anna. For military-weary Okinawa, Donald Trump offers a glimmer of hope. The Washington Post, Naha, 24 nov. 2016. Disponível em: <http://wapo.st/ 2g9G0Ix?tid=ss_mail >. Acesso em: $01 \mathrm{dez} .2016$.

FERREIRA, João Batista. Palavras dos silêncio. Cadernos de Psicanálise (CPRJ), Rio de Janeiro, ano 31, n. 22, p. 13- 36, 2009.

FERRÚS, Beatriz Antón. Silencio, se rueda. Lectora, Barcelona, n. 13, p. 11-15, 2007.

GÓES, Raïssa de. O que resta do esquecimento - uma pesquisa de artista e um olhar sobre as ruínas de Dahn Vo e as sombras de Hiroshima. In: $4^{\mathbf{0}}$ Seminário Letras Expandidas - organizado pelos alunos da Pós Graduação em Literatura, Cultura e Contemporaneidade da PUC-Rio, nov. 2015. Comunicação.

HELLER, Alberto Andrés. John Cage e a poética do silêncio. Florianópolis, 2008. 173p. Tese (Doutorado em Teoria Literária) - Centro de Comunicação e Expressão, Universidade Federal de Santa Catarina.

HUR, Hyungju. Staging modern statehood: World Exhibitions and the Rhetoric of Publishing in Late Qing China, 1851-1910. Urbana, 2012. 185p. Tese (Doutorado em Filosofia das Línguas e Culturas da Ásia Oriental) - Graduate College, University of Illinois at Urbana-Champaign.

40 残傷の音：「アジア・政治・アート」の未来へ 
JENNISON, Rebecca. Still Hear the Wound: Expanding Dialogues on Asia, Politics, and Art. In: LEE, Chonghwa (Org.). Still Hear the Wound: Toward an Asia, Politics, and Art to Come. Tradução: Rebecca Jennison e Brett de Bary (Org.). Ithaca, Nova York: The Cornell East Asia Series, 2015, p. xv-xxviii.

JENNISON, Rebecca. Unspeakable Bodies of Memory: Performance and Precarity in Recent Works by Yamashiro Chikako. Kyōto Seika Daigaku Kiyo ${ }^{41}$ (Journal of Kyoto Seika University), Quioto, n. 44, p. 181-200, 2014.

MACIEL, Adriana Sucena. ou aquilo a que chamamos arte. Rio de Janeiro, 2015. 209p. Tese (Mestrado em Literatura, Cultura e Contemporaneidade) Departamento de Letras, Pontifícia Universidade Católica do Rio de Janeiro.

MASAAKI, Aniya. Compulsory Mass Suicide, the Battle of Okinawa, and Japan's Textbook Controversy. The Asia-Pacific Journal: Japan Focus, v. 6, n. 0, p. 1-12, jan. 2008. Disponível em: <http://apjjf.org/-Aniya-Masaaki/2629/article.html>. Acesso em: 18 ago. 2016.

MIZUTAMARI, Mayumi. Comments for the panel on Lee Chonghwa's Tsubuyaki no seiji shisō. In: 'Still hear the wound': Art, Affect, and PostColonial Memory in Japan, Panel One: Poetics of Testimony and the Former 'Comfort Women` Issue, 2015, Cornell University, Ithaca (EUA). Workshop.

MORRIS, Rosalind C (Org.). Can the subaltern speak? Reflections on the history of an idea. Nova York: Columbia University Press, 2010.

MUNCH, Edvard. MM N 72 (“I was walking down a road"), Oslo, 1928-1929, Munchmuseet, Much's Writings - The English Edition. Tradução de Francesca M. Nichols. Manuscrito. Disponível em: <http://emunch.no/ TRANS_HYBRIDMM_N0072.xhtml\#.WH6wWneZPdR $>$. Acesso em: 17 set. 2016.

NOZAKI, Yoshiko; SELDEN, Mark. Japanese Textbook Controversies, Nationalism, and Historical Memory: Intra- and Inter-national Conflicts. The Asia-Pacific Journal: Japan Focus, v. 24-5-09, 15 jun. 2009. Disponível em: $<$ http://www.japanfocus.org/-Yoshiko-Nozaki/3173/article.pdf $>$. Acesso em: 26 nov. 2015.

OKAMOTO, Julia Yuri. As 'mulheres de conforto' da Guerra do Pacífico. RIC Revista de Iniciação Científica em Relações Internacionais, João Pessoa, v. 1, p. 91-108, 2013.

\footnotetext{
41 京都精華大学紀要
} 
PAJON, Céline. Understading the issue of U.S. Military Bases in Okinawa. Tradução do francês para o inglês por Nicholas Sowells. Asie. Visions, Paris, n. 29, p. 4-22, 2010.

PAZ, Octavio. Signos em rotação. Tradução de Sebastião Uchoa Leite. São Paulo: Perspectiva, 2009.

RABSON, Steve. The Politics of Trauma: Compulsory Suicides During the Battle of Okinawa and Postwar Retrospectives. Intersections: Gender and Sexuality in Asia and the Pacific, Canberra, n. 24, jun. 2010. Disponível em: $<$ http:// intersections.anu.edu.au/issue24/rabson.htm\#t37>. Acesso em: 26 nov. 2015.

REYNOLDS, Isabel; SHARP, Andy. Japan Overturns Move to Block Expansion of U.S. Base in Okinawa. Bloomberg Business, 27 out. 2015. Disponível em: $<$ http:// www.bloomberg.com/news/articles/2015-10-27/japan-overturns-move-toblock-expansion- of-u-s-base-in-okinawa>. Acesso em: 23 nov. 2015.

ROSA, João Guimarães. Buriti. In: . Noites do sertão. Rio de Janeiro: Nova Fronteira, 2013. Versão e-book.

ROSA, João Guimarães. Uma história de amor. In: . Manuelzão e Miguilim (Corpo de baile). Rio de Janeiro: Nova Fronteira, 2001. Versão e-book.

YOSHIDA, Reiji. Abe kicks off Diet session with vow to strengthen U.S. military alliance. The Japan Times, Tóquio, 20 jan. 2017. Disponível em: <http:// www.japantimes.co.jp/news/2017/01/20/national/politics-diplomacy/abe-kicksoff-diet-session-vow-strengthen-u-s-military-alliance/\#.WIJpwneZPdQ $>$. Acesso em: 20 jan. 2017.

ZOHAR, Ayelet. Camouflage, Photography and [In]visibility: Yamashiro Chikako's Chorus of the Melodies series (2010) and Beyond. Trans-Asia Photography Review, Ann Arbor, v. 3, n. 1, 2012. Disponível em: <http:// hdl.handle.net/2027/spo.7977573.0003.105>. Acesso em: 10 mai. 2015. 


\section{Mídias consultadas}

Sistema de classificação de regiões geográficas das Nações Unidas. Disponível em: <http://unstats.un.org/unsd/methods/m49/m49regin.htm\#asia >. Acesso em: 22 nov. 2015.

Blog da artista Chikako Yamashiro. Disponível em: <http://blog.goo.ne.jp/ sorashi_a-sa>. Acesso em: 12 abr. 2015.

Frame de anúncio em TV, Semp Toshiba. Disponível em: <https://youtu.be/ bWayFKSJHxE>. Acesso em: 17 nov. 2015.

Anúncio em revista, Semp Toshiba. Disponível em: <http:// www.propagandaemrevista.com.br/ propaganda/5264/>. Acesso em: 9 out. 2015.

Frase de anúncio em revista, Semp Toshiba. Disponível em: <http:// ehduca.blogspot.com.br/ 2006/06/crie-um-spot-30-para-semp-toshiba.html>. Acesso em: 21 out. 2015.

Comercial da Semp Toshiba para TV, aparelho "quebrado". Disponível em: $<$ https://youtu.be/ DIeGV6SNFcw>. Acesso em: 23 out. 2015.

Comercial da Semp Toshiba para TV, “carnaval”. Disponível em: <https:// youtu.be/ Nkggu0hO78g>. Acesso em: 23 out. 2015.

Comercial da Semp Toshiba para TV, “mestre”. Disponível em: <https://youtu.be/ Qb_EnAeBnRg>. Acesso em: 24 out. 2015.

Lei $\mathrm{n}^{\circ}$ 14.471, de 10 de julho de 2007, da Prefeitura de São Paulo. Disponível em: $<$ http://www3.prefeitura.sp.gov.br/cadlem/secretarias/negocios_juridicos/cadlem/ integra.asp?alt=11072007L\%20144710000>. Acesso em: 24 nov. 2015.

Grande festival do cabo de guerra em Naha. Disponível em: <http://www.okiislandguide.com/things_to_do/naha-great-tug-of-war-festival $>$. Acesso em: 30 out. 2015

Primeiro resultado da busca por "Okinawa" no site Google Imagens. Disponível em: <https://www.expedia.com.br/Okinawa.d10805.Guia-de-Pacotes $>$. Acesso em: 15 nov. 2015. 
Site da exposição Into the Atomic Sunshine - Post-War Art under Japanese Peace Constitution Article 9. Disponível em: <http://www.shinyawatanabe.net/ atomicsunshine/ okinawa/indexen.html>. Acesso em: 16 jul. 2015.

Fotografia tirada pela artista Yamashiro Chikako para a série Coro de melodias, publicada no site do Suijo no hito Production. Disponível em: <http:// suijonohito.com/works/chorosnouta/>. Acesso em: 24 jan. 2017.

Entrevista da artista Yamashiro Chikako publicada no site do museu Guangdong. Disponível em: <http://www.gdmoa.org/home/Exhibition_information/ Exhibition_2014/13/en/Artist/20151201/31037.shtml>. Acesso em: 02 dez. 2016. 